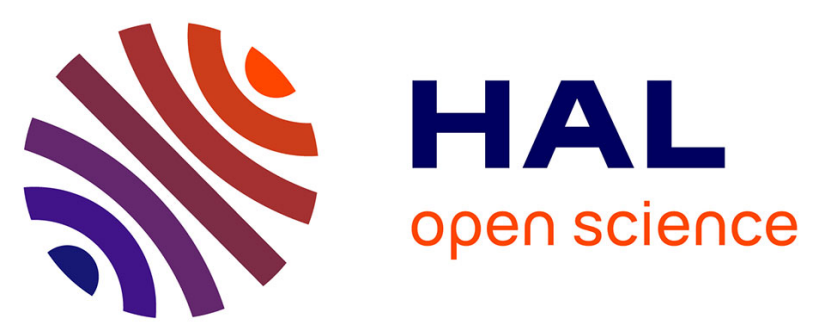

\title{
CHARACTERISTICS OF VEGETABLE OILS FOR USE AS FUEL IN STATIONARY DIESEL ENGINES - TOWARDS SPECIFICATIONS FOR A STANDARD IN WEST AFRICA
}

Joel Blin, Christel Brunschwig, Arnaud Chapuis, Odilon Changotade, Sayon Sidibe, Eric Noumi, Philippe Girard

\section{To cite this version:}

Joel Blin, Christel Brunschwig, Arnaud Chapuis, Odilon Changotade, Sayon Sidibe, et al.. CHARACTERISTICS OF VEGETABLE OILS FOR USE AS FUEL IN STATIONARY DIESEL ENGINES - TOWARDS SPECIFICATIONS FOR A STANDARD IN WEST AFRICA. RenewableandSustainableEnergyReviews, 2013, 22, pp.580-597. 10.1016/j.rser.2013.02.018 . hal-00814899

\author{
HAL Id: hal-00814899 \\ https://hal.science/hal-00814899
}

Submitted on 18 Apr 2013

HAL is a multi-disciplinary open access archive for the deposit and dissemination of scientific research documents, whether they are published or not. The documents may come from teaching and research institutions in France or abroad, or from public or private research centers.
L'archive ouverte pluridisciplinaire HAL, est destinée au dépôt et à la diffusion de documents scientifiques de niveau recherche, publiés ou non, émanant des établissements d'enseignement et de recherche français ou étrangers, des laboratoires publics ou privés. 


\title{
CHARACTERISTICS OF VEGETABLE OILS FOR USE AS FUEL IN STATIONARY DIESEL ENGINES - TOWARDS SPECIFICATIONS FOR A STANDARD IN WEST AFRICA
}

\author{
J. Blin ${ }^{a, b^{*}}$, C. Brunschwig ${ }^{a}$, A. Chapuis ${ }^{a}$, O. Changotade ${ }^{a}$,

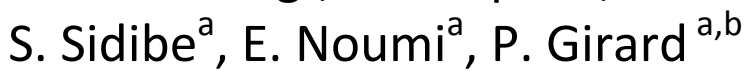

\begin{abstract}
${ }^{a}$ Institut International d'Ingénierie de l'Eau et de l'Environnement (2iE), Rue de la Science 01 BP 594, Ouagadougou 01, Burkina Faso

${ }^{b}$ Centre de Coopération Internationale en Recherche Agronomique pour le Développement (CIRAD), UPR Biomasse Energie, TA B-42/16, 73 rue Jean-François Breton, 34398 Montpellier Cedex 5, France * Corresponding author
\end{abstract}

Tel.: +226761675 59

E-mail address: joel.blin@cirad.fr

\section{Contents}

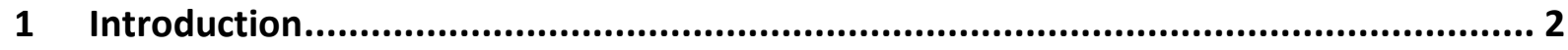

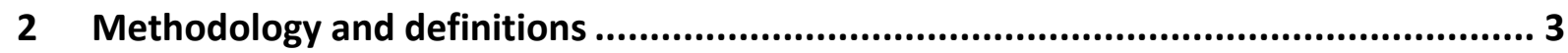

3 Straight vegetable oil as fuel for diesel engines .................................................. 4

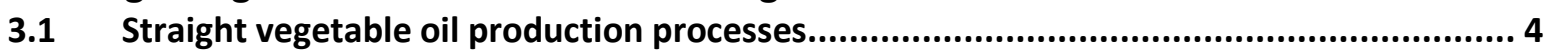

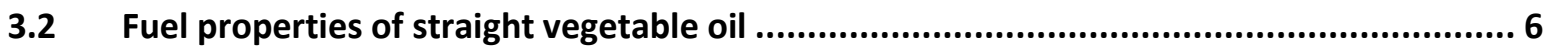

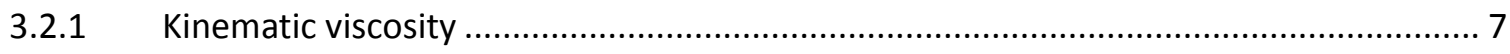

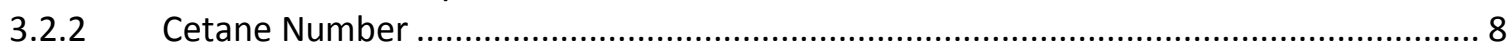

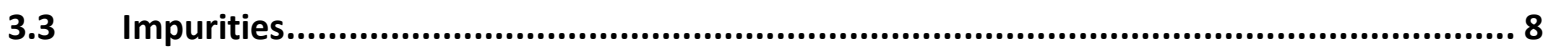

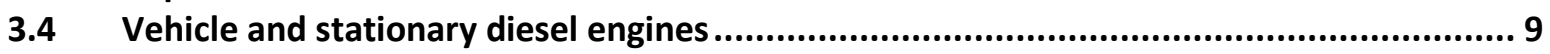

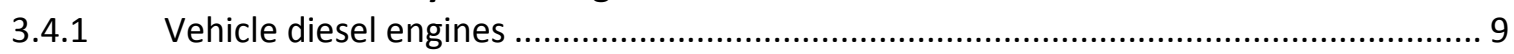

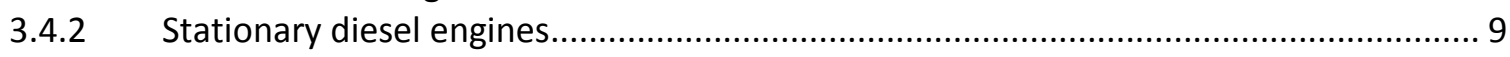

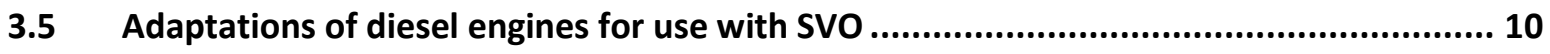

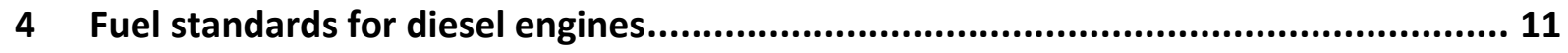

4.1 General information about fuel standards................................................................. 11

4.2 The need for an SVO standard for stationary diesel engines in West Africa.................... 11

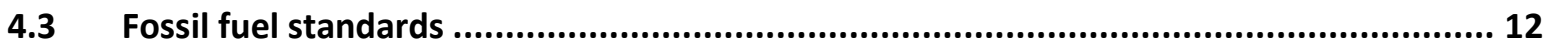

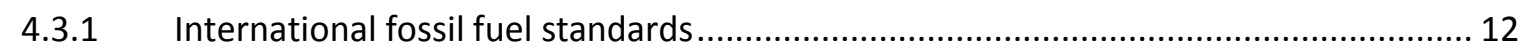

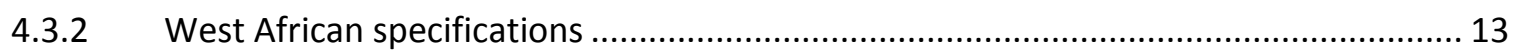

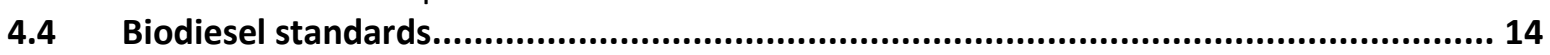

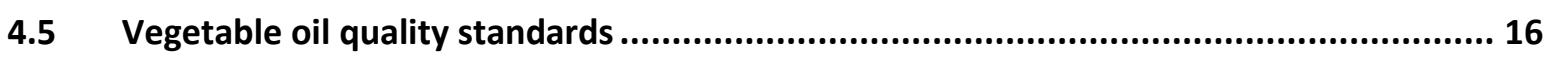

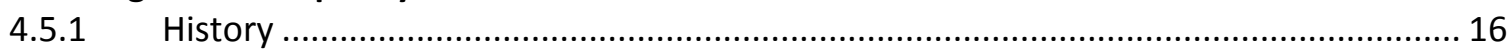

4.5.2 Pre-standard DIN V 51605: applicability and limitations ......................................... 17

5 Towards an SVO standard: Parameters, Test methods \& Limit Values ....................... 18

5.1 Selection of the relevant characteristic properties ......................................................... 18

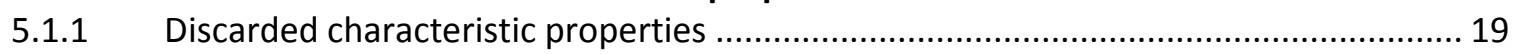

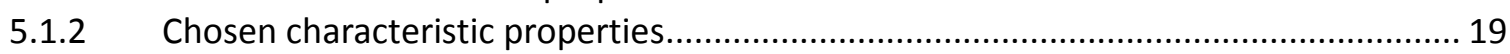

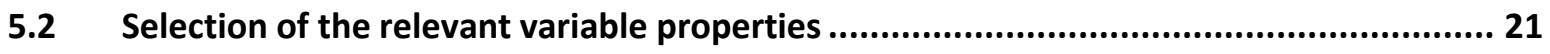

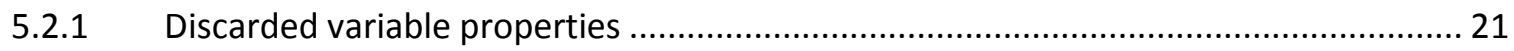

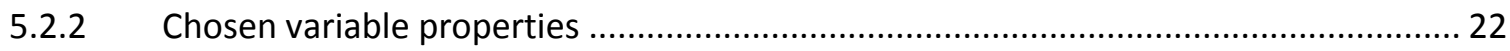

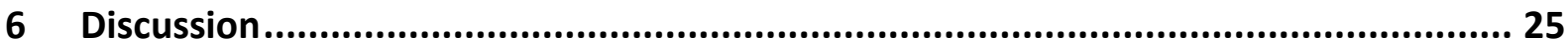

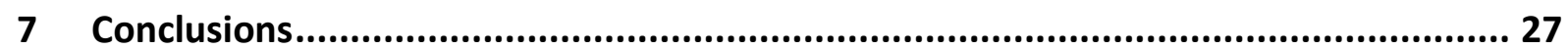




\begin{abstract}
West African countries are increasingly interested in producing straight vegetable oil (SVO) for direct use as fuel in diesel engines for stationary applications in the fields of agriculture, power generation and industry. Straight vegetable oil fuel quality, i.e impurities content and physico-chemical properties, is a recurring issue that seriously impedes the development of the sector. However, there is still no standard defining the quality characteristics of vegetable oils for fuel purposes in stationary engines. The aim of this study was to propose a quality standard with a set of specifications (parameters, test method, limit value), which SVOs must comply with in order to be used as fuel in stationary diesel engines without causing breakdowns or serious lifetime reductions. After a brief review of SVO production and use techniques, we present a critical review of existing fuel standards (fossil fuels, biodiesel and European SVO) that must be adapted to the use of SVO for stationary engines, with regard to the requirements of engine manufacturers. Based on this critical analysis and current knowledge of vegetable oil characterization, we propose a simplified, inexpensive and efficient basic standard of seven specifications. This standard enables easy assessment of SVO quality for fuelling a stationary diesel engine.
\end{abstract}

\title{
1 Introduction
}

Development of the biofuel sector is a promising option for many developing countries. Given the impending energy crisis, they are much more vulnerable than wealthy countries and ensuring their energy supply at an affordable cost will become a serious challenge in the years to come. Moreover, most southern countries do not have large investment capacities, so they have to find economical solutions to launch new economic activities in the energy production field. In this context, biofuel production is a major opportunity, particularly where large arable land areas are available and a large share of the population is involved in agriculture, such as in West Africa [1-9].

One of the most advantageous branches in the biofuel sector is seen to be the production of straight vegetable oil (SVO) for direct use as fuel in diesel engines. There has been renewed interest in this activity in recent years, for stationary applications in the fields of agriculture, power generation and industry [10-15]. These sectors are major consumers of fuel oils, either high distillates (diesel), medium distillates (DDO Distillate Diesel Oil) or heavy Fuel Oil 180 (FO180), which might be wholly or partially replaced with SVO $[10,12,13]$. This solution may contribute to reducing the cost of fossil fuel imports incurred by most developing countries, curb dependence on fossil fuels and limit greenhouse gas (GHG) emissions [14, 16-18]. This is particularly true for African countries such as Burkina Faso, Mali, Niger, Botswana, Madagascar, Malawi, Tanzania or Uganda, which import $100 \%$ of the fossil fuels they need [19].

In recent years, many initiatives for the production of oilseed-based biofuels (SVO or biodiesel) have emerged in West African countries, with the support of governments or through regional initiatives [20]. In this context, many perennial oil crops, especially Jatropha curcas, have been planted and large quantities of SVO are set to be produced in the coming years [21-26]. The most widespread scheme adopted by project promoters is the local production of oilseeds and their conversion into SVO by village-scale extraction units or decentralized cooperative mills, to fuel local stationary diesel 
engines [10, 11, 27]. This scheme has the advantage over biodiesel production of only requiring reasonable investments and offering much more flexibility in terms of production capacity, compared with large-scale centralized biodiesel production $[17,20]$.

At the beginning of these biofuel promotion campaigns, the concerns mainly focused on the agricultural part of the sector. Today, with the arrival of the first expected harvests, 3 years after planting in the case of Jatropha curcas, biofuel project developers are questioning the extraction and purification techniques, and the use of SVO in diesel engines. In such a decentralized scheme, the processing conditions can be very different from one unit to another, leading to a wide range of oil qualities. Using vegetable oil of unknown quality as fuel might be risky and rapidly cause fatal mechanical damage to engines $[13,14,28]$. Consequently, oil quality is a recurring issue that is impeding the development of the sector, since there is no standard defining what should be the quality characteristics of vegetable oils for fuel purposes in stationary engines.

Currently, no specific legal standard applies to vegetable oils for fuel uses, so by default they must comply with the quality standards of petroleum diesel fuel (set by standardization institutions such as ASTM and ISO). At the moment, SVOs rarely meet the requirements of petroleum fuel standards. Few initiatives have been launched in recent years to standardize the quality of SVO produced from a specific biomass: i) some studies were carried out in Germany on rapeseed oil [29, 30], ii) and an initiative would seem to be under way to define a standard for Jatropha curcas oil in Mali [31]. However, in all cases, the analytical methods have been derived so far from those used in petroleum fuel standards, hence designed to characterize complex mixtures of hydrocarbons, while SVOs mainly consist of quite different chemical compounds, i.e. triglycerides. As a result, certification requires a series of complicated and expensive analyses to be carried out that are not always relevant for SVO [32]. Moreover, this does not comply with the needs of small-scale oil extraction plants, which require a quick and low-cost methodology to certify an acceptable quality of SVO for fuel use in stationary diesel engines.

Consequently, the introduction of an SVO quality standard dedicated to stationary engines with low certification costs is very likely to facilitate the development of this sector in developing countries. Regional organisations such as the West African Economic and Monetary Union (WAEMU) are interested in such a norm. Local certification laboratories could be set up and guarantee good quality SVO for consumers.

The aim of this study was to consider and propose a basic set of quality criteria that SVO must comply with, in order to be used as fuel in a stationary diesel engine without causing breakdowns or serious lifetime reductions. After a brief review of SVO production and use techniques, we propose a critical review of existing tentative standards and take a look at existing experience in fuelling diesel engines with SVO, taking into account the requirements of engine manufacturers. Based on this critical analysis and current knowledge on vegetable oil characterization, we propose a simplified, cheap and efficient basic standard that enables easy assessment of SVO quality for fuelling a stationary diesel engine.

\section{Methodology and definitions}

The SVO standard proposed in this paper is based on the review and comparison of i) the literature on SVO for fuelling stationary diesel engines and ii) existing standards for diesel fuels, including fuel oils, biodiesel and SVO. All petroleum fuels dedicated to run diesel engines are grouped under the 
generic term fuel oils and SVO refers to all kinds of vegetable oils produced for fuel purposes. A standard provides a set of specifications - formed by triplets [parameter, test method, limit value] which the fuel must satisfy to claim a certified quality.

The review of fuel standards included:

- the most commonly used fuel oil standards: ASTM D-396 and ISO 3104, which are worldwide references, and the specifications recommended by SONABHY, the national oil products company in Burkina Faso, which are quite representative of those applied in West African countries.

- the main three biodiesel standards: the US standard ASTM D6751-09, the European standard EN 14214 , and the Brazilian standard ANP N7/2008.

- the tentative standard for rapeseed based SVO, DIN V 51605, which underwent several changes from 1982 to 2006.

From this review, we chose a series of parameters applicable to SVO characterization, with respect to their vegetable chemical nature.

Then, based on the current literature and knowledge on fuelling stationary diesel engines with SVO, we adopted 7 crucial parameters to be analysed for this type of application. As the test methods provided by the standards are dedicated to petroleum products, they are not always suitable for vegetable oil characterization. We therefore propose appropriate and simple analytical methods, partially based on those recommended for the "Standardization of edible vegetable oils" [33], found in the Codex alimentarius, paying special attention to certification costs.

Lastly, the limit values for each parameter are discussed, with regard to those prescribed for stationary applications by the reviewed standards.

\section{Straight vegetable oil as fuel for diesel engines}

\subsection{Straight vegetable oil production processes}

SVOs are usually produced by mechanical extraction of oil from an oil-bearing biomass as feedstock. SVOs have a chemical composition that corresponds in most cases to a mixture of $95 \%$ triglycerides and $5 \%$ free fatty acids, sterols, waxes and various impurities [34-37]. The quality of SVO for fuel use is strongly influenced by both the quality of the feedstock and the processing conditions, which need to be carefully managed to obtain high quality fuel. Oilseeds come from dedicated crops (sunflower, rapeseed, oil palm, Jatropha curcas, etc.) or crop by-products (cotton, flax, etc.). There are five main operations in the SVO production process that govern fuel quality and which need to be carefully managed (see figure 1).

1-Seed storage: seeds may be stored over several months to fit in with process planning. They must be regularly aired to prevent acidification and heat build-up [13]. Batches are considered to be stabilized if their moisture content is below $9 \%$ in weight [38]. Moreover, this is the maximum seed moisture content for most screw-presses currently available on the market to operate efficiently [39].

2- Pre-treatments: firstly, impurities (leaves, soil, stones, metallic objects, etc.) in the seeds must be eliminated to a maximum of $2 \%$ [38] by weight. In particular, they cause wear in the press, increasing impurity levels in the oil. Then, cooking pre-treatment of the seeds is a commonly used technique to facilitate oil expression and thereby increase pressing capacity and oil recovery: this is due to the 
thermal rupture of oil cell walls at temperatures above $100^{\circ} \mathrm{C}[39,40]$. However, this is likely to raise phosphorus concentrations in the oil, known to cause clogging in diesel engines [13, 41].

3-Mechanical extraction: the most common production process consists of mechanical extraction [42] of oil from the seeds using a screw press. The mechanical strains inside the barrel are high, up to $40 \mathrm{MPa}$ and friction phenomena increase the temperature of the seed mixture, up to $150^{\circ} \mathrm{C}$ in some cases [43]. However, the extraction temperature should be kept below $80^{\circ} \mathrm{C}$ to avoid the dissolution of a large amount of phosphorus in the oil. Thus, producing high quality SVO requires appropriate equipment and a highly skilled press operator.

4- Filtration: after extraction, the oil is simply filtered and can be purified by chemical operations such as degumming and neutralization. Filtration removes most solid impurities from the oil (particles, waxes, phospholipids) for a better quality fuel. Oils can be directly filtered after extraction or filtered after letting the oil decant for several days or even a few weeks (3-4 weeks) [13, 44]. Filtration should be carried out between $20^{\circ} \mathrm{C}$ and $60^{\circ} \mathrm{C}$ [13] to remove all soluble particles. Above $60^{\circ} \mathrm{C}$, there are also some risks of oil oxidation. In most publications, it is recommended to filter at 10 $\mu \mathrm{m}$ to prevent any contamination and impurities in the oil [45].

5- Oil storage: once filtered, to ensure good quality fuel, SVOs have to be stored in clean, air-tight, containers, in a cool $\left(<35^{\circ} \mathrm{C}\right)$ and dark storage area to prevent oil oxidation and acidification leading to higher viscosity and engine filtration problems.

If free fatty acid contents or phospholipid contents are too high, additional refining operations can be performed to improve SVO quality, i.e. neutralisation and degumming respectively.

Neutralisation consists in adding an alkali to the oil, typically $\mathrm{NaOH}$, to turn the free fatty acids into soaps and then separate them by sedimentation. Degumming is commonly achieved by mixing water with the oil at high temperature: phospholipids are hydrated, forming solid particles that can be removed by centrifugation. Both processes are followed by a drying process, which makes them very energy-intensive and produces wastewater [46].

These operations have been developed in the edible oil industry and are not likely to be applied in small-scale SVO production processes. However, recent research work has proved that membrane filtration technologies allow dry degumming and neutralisation, at low temperatures $\left(20^{\circ} \mathrm{C}\right)$. This process would be much more efficient, with lower operating costs, and thus available on a smaller scale [47]. 


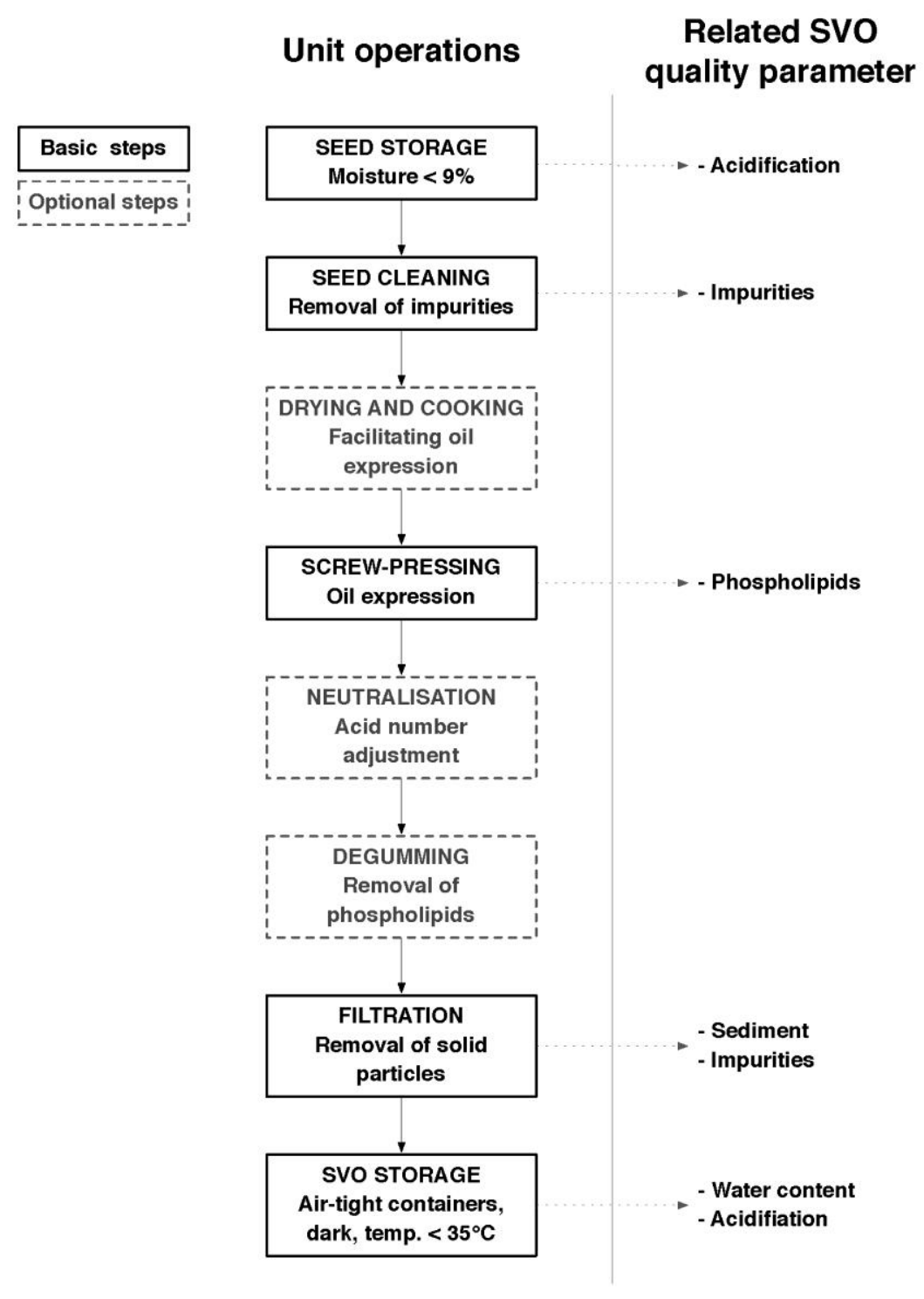

Figure 1: SVO quality in relation to the production process

\subsection{Fuel properties of straight vegetable oil}

Vegetable oils are mainly composed of triglycerides that consist of one molecule of glycerol combined with three molecules of fatty acids. The latter contain a long chain of carbon atoms, linked by single bonds and combined with hydrogen, ending with a carboxyl group [48]. Fossil fuel oils are complex mixtures of hydrocarbons which contain paraffins, naphthenes, olefins, and aromatics [13, 28]. As shown in Table 1, despite a different chemical composition, vegetable oils have similar fuel properties to petroleum-derived diesel fuels, so they are suitable for fuelling diesel engines [49, 50]. SVOs have several advantages over fuel oil for use as fuel in stationary diesel engines: i) local availability, ii) renewability, iii) relatively high HHV, iv) a lower sulphur content, avoiding the environmental issues caused by sulphuric acid, v) a lower aromatic content and vi) high biodegradability $[13,28,51]$.

However, due to the high viscosity of SVOs and their low cetane number, slight engine adaptations are required and specific operating precautions need to be observed. 


\subsubsection{Kinematic viscosity}

SVO viscosity is much higher than that of diesel fuel: it increases with the carbon chain lengths [28, 52], triglyceride unsaturation which induces polymerization, and when the temperature decreases [51]. Common SVOs have a kinematic viscosity of $30-40 \mathrm{cSt}$ at $40^{\circ} \mathrm{C}$, (see Table 1) i.e. 10-15 times higher than that of diesel [28, 37, 53-55].

SVO high viscosity causes i) a decrease in injection rate due to head losses in fuel injection pumps, filters and injectors, ii) poor fuel atomization and vaporization by the injectors, which leads to incomplete combustion inside the combustion chamber [51, 56, 57]. This results in lower thermodynamic efficiency, and an increase in soot emissions and particles.

SVO kinematic viscosity does not meet the requirements of diesel fuel standard ASTM D396, which sets a limit value of 2-3.6 cSt and 5.8-26.4 cSt at $38^{\circ} \mathrm{C}$ for grade No. 2-D (diesel) and grade No. 4-D (medium distillate) respectively. For low-speed stationary engines, manufacturers recommend an optimum kinematic viscosity of between 13 and $17 \mathrm{cSt}$ for fuel before entering the pump [58]. As for heavy fuel, the kinematic viscosity of SVO at room temperature exceeds the required range, thus needing pre-heating to reduce it $[48,59]$. As shown in figure 2 , for a typical heavy fuel viscosity of $180 \mathrm{cSt}$ at $50^{\circ} \mathrm{C}$, it is necessary to heat the HFO to between $114^{\circ} \mathrm{C}$ and $125^{\circ} \mathrm{C}$ to reach the appropriate viscosity, while SVOs require only $67^{\circ} \mathrm{C}$ to $78^{\circ} \mathrm{C}$ to achieve the same viscosity.

\begin{tabular}{|c|c|c|c|c|c|c|c|c|c|c|}
\hline Feedstock & $\begin{array}{c}\text { Density } \mathrm{kg} / \mathrm{m}^{3} \text { at } \\
15^{\circ} \mathrm{C}\end{array}$ & $\begin{array}{c}\text { Kinematic } \\
\text { viscosity (cS) }\end{array}$ & $\begin{array}{l}\text { Cetane } \\
\text { Number }\end{array}$ & $\mathrm{HHV} \mathrm{MJ/kg}$ & $\begin{array}{c}\text { Flash } \\
\text { point }{ }^{\circ} \mathrm{C}\end{array}$ & $\begin{array}{c}\text { Carbon } \\
\text { residue \%wt }\end{array}$ & $\begin{array}{c}\text { lodine } \\
\text { value } g I_{2} / g\end{array}$ & $\begin{array}{c}\text { Pour point } \\
\left({ }^{\circ} \mathrm{C}\right)\end{array}$ & $\begin{array}{c}\text { Sulphur } \\
\text { Wt. } \%\end{array}$ & References \\
\hline $\begin{array}{l}\text { Diesel } \\
\text { (SONABHY) }\end{array}$ & 820 to 890 & 1.6 to $5.9^{\mathrm{a}}$ & $>50$ & $>45.0$ & $>61$ & $<0.15$ & - & - & $<1.0$ & [80] \\
\hline $\begin{array}{l}\text { DDO } \\
\text { (SONABHY) }\end{array}$ & 835 to 950 & 5.9 to $15^{a}$ & $>40$ & $>44.70$ & $>66$ & $<0.2$ & - & $<15$ & $<1.5$ & {$[80]$} \\
\hline $\begin{array}{l}\text { Fuel-oil } 180 \\
\text { (SONABHY) }\end{array}$ & 920 to 990 & $<180^{\mathrm{c}}$ & $>30$ & $>43.00$ & $>66$ & $<12$ & - & $<15$ & $<3$ & {$[80]$} \\
\hline $\begin{array}{l}\text { Biodiesel } \\
\text { (EN14214) }\end{array}$ & 860 to 900 & $3.5-5.0^{b}$ & $>51$ & - & 120 & 0.3 & 120 & - & 1 & [84] \\
\hline Babassu & 946 & $30^{a}$ & 38 & - & 150 & - & 16 & - & - & {$[51,99,125]$} \\
\hline Castor & 955 & $251^{b}$ & 42 & 37.4 & - & - & $83-86$ & - & - & {$[51,99,125]$} \\
\hline Coconut & 918 & $27^{b}$ & $40-42$ & 37.1 & - & - & 8-11 & - & 0.01 & {$[51,99,125]$} \\
\hline Corn & 910 & $31-35^{a}$ & 38 & 39.5 & 277 & 0.24 & $103-128$ & -40 & 0.01 & {$[51,99,125]$} \\
\hline Cottonseed & 915 & $34^{b}$ & 42 & $38.7-39.5$ & 234 & 0.24 & 103-115 & -15 & 0.01 & {$[51,99,125]$} \\
\hline Crambe & 905 & $54^{a}$ & 45 & 40.5 & 274 & 0.23 & - & -12 & & {$[51,99,125]$} \\
\hline Jatropha & 940 & $34^{b}$ & 39 & 38.8 & 225 & - & $82-98$ & & 0.01 & {$[51,99,125]$} \\
\hline Linseed & 924 & $26-27^{a}$ & 35 & 39.3-39.5 & 241 & 0.22 & 180 & -15 & - & {$[51,99,125]$} \\
\hline Mahua & 960 & $25^{b}$ & - & 36 & 232 & - & $58-70$ & - & - & {$[51,99,125]$} \\
\hline Neem & 919 & $50^{b}$ & - & - & - & - & $65-80$ & - & - & {$[51,99,125]$} \\
\hline Palm & 918 & $40^{a}-45^{b}$ & 42 & 39.5 & 267 & 0.23 & $48-58$ & - & 0.01 & {$[51,99,125]$} \\
\hline Peanut & 903 & $40^{b}$ & 42 & 39.8 & 271 & 0.24 & $84-100$ & -7 & 0.01 & {$[51,99,125]$} \\
\hline Rapeseed & 912 & $35-37^{a}$ & 41 & 39.7 & 246 & 0.3 & 105 & -32 & 0.01 & {$[51,99,125]$} \\
\hline Sesame & 913 & $36^{b}$ & $40-42$ & 39.4 & 260 & 0.24 & 103-116 & -9 & 0.01 & {$[51,99,125]$} \\
\hline Soybean & 914 & $29^{b}-33^{a}$ & 38 & 39.6 & 254 & 0.25 & $128-143$ & -12 & 0.01 & {$[51,99,125]$} \\
\hline Safflower & 914 & $31^{a}$ & 41 & 39.5 & 260 & 0.25 & 145 & -7 & & {$[51,99,125]$} \\
\hline Sunflower & 916 & $34^{a}-36^{b}$ & 37 & 39.6 & 274 & 0.27 & $125-140$ & -15 & 0.01 & {$[51,99,125]$} \\
\hline
\end{tabular}

Table 1: Fuel properties of different vegetable oils compared to fossil fuels

${ }^{a}$ kinematic viscosity at $37.8^{\circ} \mathrm{C} ;{ }^{b}$ kinematic viscosity at $40^{\circ} \mathrm{C} ;{ }^{c}$ kinematic viscosity at $50^{\circ} \mathrm{C}$ 


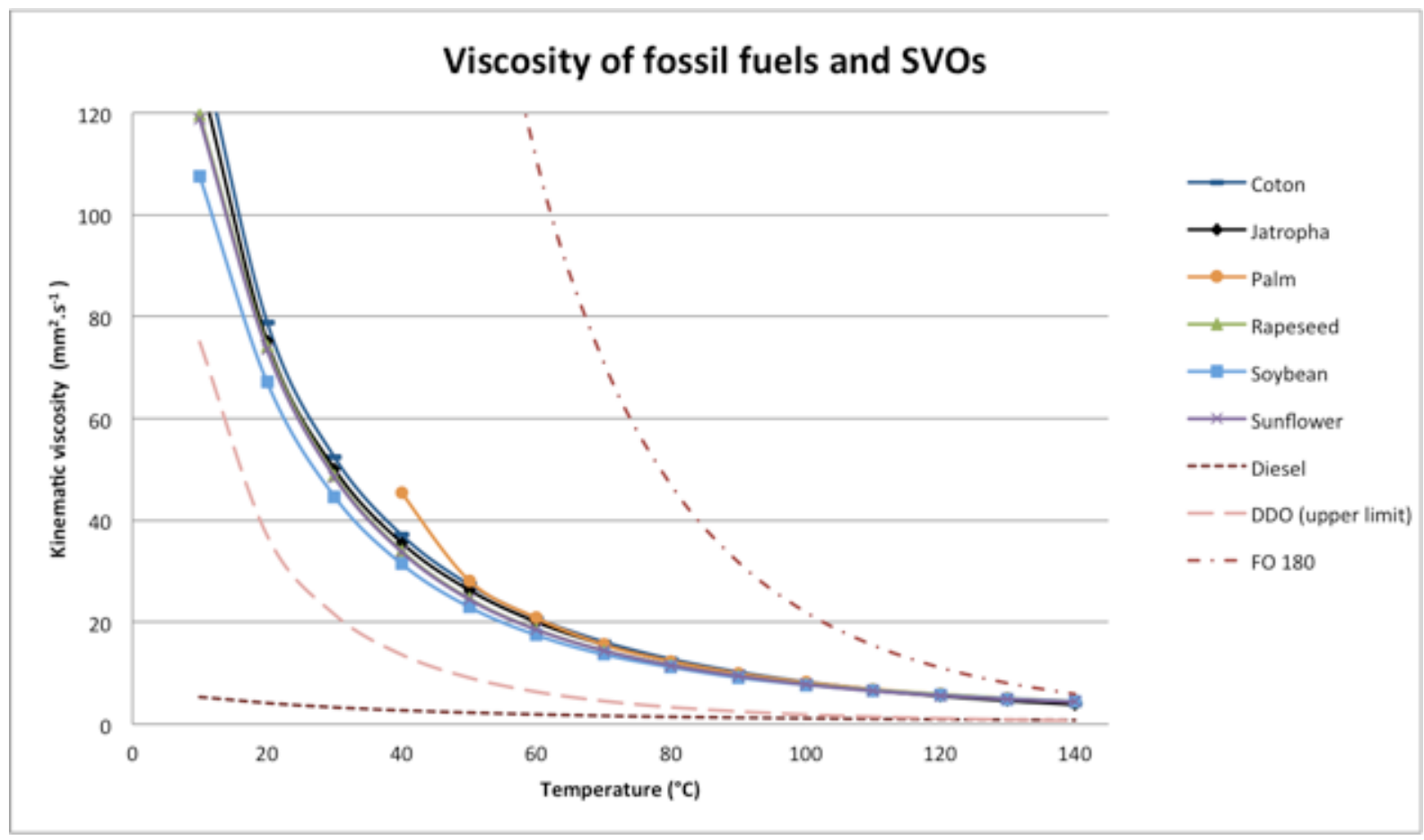

Figure 2: Temperature dependence of the kinematic viscosity of vegetable oil and different heavy fuel oils [48,58,59]

\subsubsection{Cetane Number}

The cetane number reflects the ability of a fuel to self-ignite when compressed under standardized conditions [13]. It is a direct indicator of the ignition delay of the fuel in the combustion chamber after its injection. The higher it is, the easier the fuel is to ignite (easy cold start). The cetane numbers obtained for most vegetable oils are low, between 29 and 43, as opposed to at least 45 for diesel and 40 for DDO, but they are within the range of Fuel-Oil 180 (Table 1). As for diesel, this low cetane number for vegetable oils leads to incomplete combustion when the engine is idling, difficult cold starting of the engine and increased engine noise. It is known that the self-ignition delay of fuels decreases as their injection temperature increases $[28,60,61]$.

\subsection{Impurities}

Depending on the quality and cleanness of the biomass used upstream and the extraction and storage conditions, vegetable oils can contain impurities that might lead to engine faults or damage when used as fuel. According to most authors, the most harmful impurities for diesel engines are phospholipids, sediments, high free fatty acid contents and water:

- Phospholipids come directly from the breakdown of cell membranes within the plant biomass [45]. Their concentration depends on the extraction techniques used, and especially the temperatures reached during cooking treatment and pressing; high temperature conditions cause phospholipids to dissolve in oils. When the oils are used in an engine, the phospholipids polymerize under the effect of heat and are responsible for the formation of deposits that clog injectors and valves, and build up on the combustion chamber walls and cylinder surfaces $[13,45]$.

- Sediments can be of two kinds, either organic or mineral [58]. In the first case it may involve fragments that come directly from the breakdown of plant tissues, or from particles that are formed via reactions polymerizing free fatty acids, or other minority compounds formed during storage. Unsuitable storage conditions (presence of air, light, metal tanks, etc.) are conducive to the formation of organic sediments. Sediments of mineral origin come from impurities (sand, soil) that 
have not been totally separated from the biomass prior to extraction. As some sediments dissolve when hot, it is preferable to filter oils cold $\left(<50^{\circ} \mathrm{C}\right)$, after a possible sedimentation stage enabling separation of the densest sediments by gravity (see section 3.1 ).

Although sediments do not cause any real combustion difficulties, they can cause peripheral engine parts, such as filters or pumps, to malfunction. Indeed, sediments may clog the fuel filter and cause additional losses in the circuit, leading to a very significant increase in the injection pressure $[37,53]$. Mineral sediments, which are the most harmful because they are highly abrasive, damage fuel feed circuits and the inner wall of the combustion chamber [58].

- The acidity of oils is mainly due to the existence of free fatty acids from the hydrolysis of triglycerides in the presence of water [38]. Such hydrolysis reactions may take place in the biomass if it is stored under poor conditions (moisture), during pressing if the temperatures are too high, and during oil storage in the presence of water and light. Oil acidity is responsible for damage to engine feed circuits (hose, gasket, etc.) , engine corrosion and SVO instability during storage $[37,60]$.

- Water present in oils comes directly from biomass that has been poorly dried, or from condensation under poor oil storage conditions [58]. Water hydrolyses triglycerides to form free fatty acids. The presence of water in vegetable oil deteriorates fuel filter cartridges [60]. In addition, during combustion, the existence of water causes cavitation events, particularly at the piston head [62], which may cause serious damage. In general, the presence of water in a fuel is detrimental, as it lowers the heating value, disrupts ignition and slows down flame propagation.

\subsection{Vehicle and stationary diesel engines}

Diesel engines are used rather for heavy applications, mainly for transport (road, rail or sea), producing shaft power (agriculture, industry) or electricity generation. They are internal combustion engines with spontaneous ignition of the air/fuel mixture under the combined effect of pressure and temperature. They are designed to run on fossil fuels called fuel oils, such as high distillates (diesel), medium distillates (such as DDO Distillate Diesel Oil) or low distillates (such as Fuel Oil 180). Diesel engines are divided into two major categories, vehicle diesel engines used for transport, and stationary diesel engines used for shaft power and/or electricity generation, and in the marine sector.

\subsubsection{Vehicle diesel engines}

Vehicle diesel engines, used in the transport sector, operate at high speeds $(4,000-5,000 \mathrm{rpm})$ and are designed to withstand very variable operating conditions (in terms of speed and load) depending on traffic conditions and vehicle weight. This leads to considerable temperature variations in the combustion chamber [63]. Given their low cetane number their combustion may be incomplete and form deposits that foul the engine. Consequently, it seems difficult to fuel a vehicle engine with vegetable oil in the long term. It is definitively not recommended with last generation engines (common rail injection).

\subsubsection{Stationary diesel engines}

Stationary diesel engines are designed to produce shaft power with high efficiency around the rated speed [63]. They are generally used for applications where load variations are limited, which guarantees high combustion temperatures, provided the engine is correctly sized. Unlike vehicle engines, stationary engines operate at slow speeds (900 rpm at the most for the smallest), with high compression rates. These characteristics provide better combustion conditions, notably longer residence times and higher temperatures, so that fuels with lower cetane numbers can be used. 
These engines are therefore perfectly suitable for use with fuels such as DDO, Fuel Oil 180 or SVO with lower cetane numbers than diesel.

\subsection{Adaptations of diesel engines for use with SVO}

Since their invention in 1892 by Rudolf Diesel, diesel engines have been improved to become highly efficient. Consequently, the current engines are optimized for the fuels they are designed for and are not flexible enough to enable optimum combustion of vegetable oils in the combustion chamber [64].

In order to alleviate the problems of SVO injection and combustion in engines due to their high viscosity and low cetane number, it is necessary to proceed in the same way as when heavy fuels such as Fuel Oil 180 are used. It is necessary to i) pre-heat the fuel to make it more fluid and ii) preheat the engine with a light fuel (diesel) in order to increase the average temperature inside the combustion chamber $\left(>500^{\circ} \mathrm{C}\right)$ and enable rapid and complete combustion [13]. The combustion engine temperature at which it becomes possible to inject vegetable oils is defined by measuring the temperature of the exhaust gas. However, as diesel engines vary in design, it is preferable, when possible, to test the engine with SVOs to define beforehand the lowest temperature at which oil combustion is complete. To do so, the recommendation is to analyse engine exhaust gases at various load rates. As the engine load rises, the temperature of the exhaust gases increases and the unburnt fuel and CO contents of the exhaust gases decrease. The temperature at which SVO combustion becomes acceptable is reached once the unburnt fuel and CO contents of the exhaust gases are close to those obtained when operating on diesel oil at the same engine load. On average, this temperature is reached at $70 \%$ of maximum engine load [13][7].

From a practical viewpoint, two options can be used to apply the principles described above to run stationary diesel engines on SVOs; it is necessary to either i) blend SVOs with diesel at a low oil content $[35,65]$, or ii) adapt engines for dual-fuelling [35, 65]:

The blending solution overcomes SVO viscosity and injection problems, hence the combustion problem. However, in order for the blend to retain combustible properties close to those of fuel oil, SVOs must not be used in proportions exceeding $30 \%[13,53]$. This blend solution is often chosen when only small quantities of vegetable oils are available [66]. However, operators may be tempted to incorporate oil contents exceeding $30 \%$, which would rapidly result in engine fouling and (often irreversible) mechanical breakdowns.

Dual-fuelling systems can be used to run a diesel engine, once hot, with $100 \%$ SVO. It consists in equipping the stationary engine with an extra fuel tank, for SVO, and a system of valves (electronically or manually controlled) making it possible to switch the feed from one fuel to the other. The diesel/SVO switch-over conditions are controlled as follows:

- as long as the combustion chamber (in fact the exhaust gases) has not reached the target temperature levels for good vegetable oil combustion, the engine continues to be fed with diesel oil [13].

- as soon as the target exhaust gas temperature is reached, the valve is switched (manually or through a switch-over system which activates a solenoid valve) to feed the engine via the vegetable oil circuit [67].

- before the engine is stopped, it has to be fed again for a few minutes with diesel oil to flush the entire feed circuit and enable an easy cold start the next time [13].

This dual-fuelling of stationary engines is commonly used in West African power stations that use diesel oil and DDO for the engine start-up and pre-heating phases, and then switch to $100 \%$ Fuel Oil 180. 


\section{$4 \quad$ Fuel standards for diesel engines}

Historically, Rudolf Diesel tested his prototype engine on peanut oil at the 1900 World Fair in Paris [68]. His patent was registered in 1892 under the name of "heavy oil engine", i.e. that runs on vegetable oils or residues from petroleum distillation as fuel [68]. In 1921, ASTM published the first tentative standard for "distillation of petroleum products at atmospheric pressure" (ASTM D 86-05) [69]. Then, several other international test methods for specific petroleum-derived fuels (Fuel Oil, DDO, etc.) were developed from the 1920s through to the 1940s [69]. Since the 1980s, biodiesel standards have been extensively developed [51] and are commonly used. More recently, with the recent renewed interest in vegetable oil as fuel, the Deutsche Institut für Normung proposed a specific quality pre-standard for rapeseed oil in 2006 [70] (DIN 51605).

However, so far, there has been no generic standard for SVO, whatever the nature of the oil. The existing pre-standard for rapeseed oil showed some limitations for our purpose: since it is mainly based on diesel standards, some parameters, limit values, or even test methods that are relevant for hydrocarbon products are not suitable for characterizing SVOs.

This pre-standard therefore needs some adjustments to be applicable to any type of vegetable oil and not only to rapeseed oil, to enable use in stationary diesel engines. The standard that is to be proposed must bring into play analytical techniques that are accurate and simple to apply so that they can be performed with conventional equipment in the largest possible number of quality control laboratories in Africa. Such a pre-standard is essential if the use and trading of vegetable oils as fuel are to develop.

\subsection{General information about fuel standards}

In order to guarantee optimum and durable diesel engine operation, manufacturers recommend using standardized fuels. To that end, the physico-chemical properties of the fuel must correspond to the specifications set down by the standards.

The purpose of the standards is to certify a set of characteristics and a composition for each fuel that i) guarantee good performance when used in engines (efficiency, mechanical performance, endurance, atmospheric emissions, etc.) and ii) make it possible to estimate and foresee the potential impacts of using, transporting and/or storing these fuels on health and the environment. All fuel standards have their own specifications that can be classified in line with their relation to i) the origin of the fuels (fossil/vegetable), ii) the process used to synthesize/refine/purify them, and iii) the type of application (stationary, marine or transport diesel engine).

These standards are issued by national or international organizations present in the different geographical zones of the world including, among others, the American Society for Testing and Materials (ASTM) in the United States, the Institute of Petroleum (IP, London, United Kingdom), the Association Française de Normalisation (AFNOR, Paris, France), the Deutsche Institut für Normung (DIN, Germany), and the International Organization for Standardization (ISO, Geneva, Switzerland). The aim of these organizations is to guarantee a minimum quality for fuels according to their uses, and to protect users and the environment.

\subsection{The need for an SVO standard for stationary diesel engines in West Africa}

Nowadays, oilseed biofuels appear to be an interesting alternative to fossil fuels, notably in West African countries. The different governments in those countries have understood this, since they 
have all started defining national strategies. These initiatives have advanced to varying degrees depending on the countries.

Unlike the approaches taken by European countries, the USA and Brazil, who are considering developing biofuels almost exclusively by replacing fossil fuels in the transport sector, African countries are primarily targeting the shaft power and electricity generation sectors [21], which may have a wider social impact considering the weakness of rural energy access in those countries.

Land use and potential competition between food and energy is an essential question and debate cannot be avoided $[1,71,72]$. Situations may vary from country to country and a generic position is not possible. However, Africa in general and West Africa in particular present large areas of arable land (as defined by the FAO only $27 \%$ of African cultivable land is in use [73]). At the same time, those countries show one of the lowest yields per ha for most crops, one of the reasons being a lack of access to energy. Consequently, if the question of land availability is considered carefully, there is a huge potential for bioenergy, particularly when considered with appropriate land, manpower and water management. This suggests a real prospect of improved food security through better use of the whole plant, synergies between crops and cropping systems, and access to energy including storage and transformation $[3,71,74]$.

\subsection{Fossil fuel standards}

Diesel fuels were originally straight-run products obtained from the distillation of crude oil. Depending on the intended application, a wide range of more or less complex and viscous oil products can be used as fuel in diesel engines [75]. These fuels are fractions obtained from petroleum, either as a distillate or a residue. Currently, diesel fuel may also contain varying amounts of selected cracked distillates [76].

Light volatile distillate fuel oils such as diesel, with a high cetane number, are used in cars and trucks for transport applications $[69,77]$.

The viscous residual fuel oils are used in large stationary and marine engines and usually require preheating for proper pumping, injection, and atomization $[75,76]$. Generally, heavy fuel oils consist of residual oils blended with distillates to suit specific needs. Included among heavy fuel oils are various industrial oils and bunker oils [76].

Unlike vegetable oils, whose triglyceride chemical composition is always the same whatever the biomass feedstock, the chemical compositions of diesel fuels are variable depending on the nature of the original crude oil, the refining processes by which the fuel is produced, and the additive used (if any).

Consequently, depending on the countries, the standards bodies, and the targeted applications and properties of the original crude oil, the specifications for fuel oils exist in various combinations of characteristics [75]. Concretely, this means that engine manufacturers recommend using fuels with specifications that vary from one manufacturer to another depending on their nationality and their sales area.

\subsubsection{International fossil fuel standards}

Basically, there is no universal classification for petroleum-derived fuel. Initially, petroleum-derived fuels were classified and standardized according to the process used to obtain them. Nowadays, with the very broad variety of petroleum-derived products and the various standards bodies, there is a plethora of fuel standards that depend on the type of targeted applications rather than the refining process. 
ASTM D-396 called "Standard Specification for Fuel Oils" is the most widely used standard to qualify fuel oils [69, 76-78]. It specifies six different grades of fuels.

Grades No. 1-D and 2-D are distillate fuels commonly used in high-speed engines of the mobile type, in medium speed stationary engines, and in most railway engines [69, 76-78].

Grade No. 3-D covers distillate fuel oils which are rarely used.

Grade No. 4-D covers the class of more viscous distillates (medium distillate). It can be seen as a heavy diesel, which is used as fuel in some stationary engines or in burners for heat applications. In some countries, such as West African countries, fuel oil No. 4-D is sold as DDO (for Distillate Diesel Oil).

Grade No. 5-D covers residual type industrial oils requiring preheating to $77-104^{\circ} \mathrm{C}$ for proper atomization in engines or burners. It may be obtained from the heavy gas oil cut, or it may be a blend of residual oil with enough No. 2-D fuel oil to adjust viscosity. Bunker B is one of the No. 5-D fuel oils Grade No. 6-D covers high-viscosity residual oils requiring preheating to $104-127^{\circ} \mathrm{C}$ which are used for thermal power plants (RFO for residual fuel oil) and for ships as marine fuel (HFO for heavy fuel oil) or bunker fuel oils (Bunker C) [76, 77].

\subsubsection{West African specifications}

In almost all West African countries, three types of fuel oils are available for diesel engines: Diesel, Distillate Diesel Oil (DDO) and Fuel Oil 180 (FO 180). During work to harmonize specifications in the ECOWAS market, it appeared that specifications for oil products varied slightly from one country to the next [79]. As a reference, specifications for these three fuels, such as defined by the national hydrocarbon import company (SONABHY) [80] in Burkina Faso, are given in Table 2. Diesel is a light No. 2-D fuel oil with a relatively high sulphur content reaching a maximum 10,000 ppm (i.e. $1 \%$ by weight) compared to northern countries of Europe, where diesel contains under $10 \mathrm{ppm}$ of sulphur. It is mainly used for transportation. However, as diesel is better distributed inside the countries than the other two fuel oils, it is also often used by small operators in decentralized areas to run small stationary engines (mills, generators, pumps, etc.). In 2007, diesel amounted to more than half the total national consumption of liquid fuels in Ivory Coast and Mali. It was close to one third in Burkina Faso [19].

DDO is a No. 4-D fuel oil with less stringent specifications than diesel and, in particular, with a higher viscosity and a higher sulphur content. Due to its high viscosity, DDO is not a suitable fuel for car and truck engines, but it perfectly suits all types of stationary engines providing shaft power and/or electricity. DDO is about 30\% cheaper than diesel in most countries and, moreover, when it is used for power generation in decentralized areas, it is subsidized or untaxed by states.

Fuel Oil 180 is a No. 5-D fuel oil. It is actually a mixture of residual fuel oil and No. 2-D fuel oil formulated to achieve a maximum viscosity of $180 \mathrm{cSt}$ at $50^{\circ} \mathrm{C}$. It is mainly used as fuel for large stationary engines (>18MW) used in thermal power plants. Due to its very high viscosity, it has to be preheated before being pumped, injected and burned in engine combustion chambers. So, engines using this fuel are equipped with a dual fuel system.

According to the Deutsche Gesellschaft für Technische Zusammenarbeit (GTZ), 64\% of the total electricity in West Africa in 2009 was generated from fossil fuel [81]. Moreover, most generators and stationary diesel engines sold in West Africa are designed to operate with diesel and DDO. There are very few generators running on FO 180 (only 3 in Burkina Faso) but as these are generating sets of large power stations, they consume significant quantities of fuel. For example, out of 522 ktoe of liquid fuel imported into Burkina Faso in 2008, 34.5\% was diesel, 11.4\% DDO and 13.7\% FO 180 [20]. 
In this context there is thus a real market for vegetable oil fuel in Africa. Local production of this fuel could be a way of developing electricity production and extending its access to a larger segment of the population.

Table 2 shows that the physico-chemical properties of SVO (i.e. cetane number, density, viscosity, etc.) are closer to those of DDO than those of diesel. This implies, as mentioned in section 3.2, that SVOs, like DDO, are suitable for use in stationary engines. It means, unlike what has been done so far with the rapeseed oil pre-standard, that in a strategy for defining specifications for SVO use as a fuel for stationary diesel engines, it is better to take inspiration from DDO specifications rather than from diesel specifications.

\begin{tabular}{|c|c|c|c|c|c|c|}
\hline \multirow{2}{*}{ Property } & \multirow{2}{*}{ Units } & \multicolumn{3}{|c|}{ Limits } & \multicolumn{2}{|c|}{ Test method } \\
\hline & & FO 180 & DDO & Diesel & ASTM & AFNOR \\
\hline Density at $15^{\circ} \mathrm{C}$ & $\mathrm{kg} / \mathrm{L}$ & 0.920 to 0.990 & 0.835 to 0.950 & 0.820 to 0.890 & D4052 or D1298 & T60 101 \\
\hline Kinematic viscosity & cSt & $\begin{array}{l}\text { Max } 180 \\
\text { at } 50^{\circ} \mathrm{C}\end{array}$ & $\begin{array}{l}5.9 \text { to } 15 \\
\text { at } 37.8^{\circ} \mathrm{C}\end{array}$ & $\begin{array}{l}1.6 \text { to } 5.9 \\
\text { at } 37.8^{\circ} \mathrm{C}\end{array}$ & D445 & T60 100 \\
\hline Cetane index & & Min 30 & Min 40 & Min 50 & D976 & \\
\hline Higher Heating Value & $\mathrm{kJ} / \mathrm{kg}$ & Min 43000 & Min 44700 & Min 45000 & Calculated & M07 030 \\
\hline Lower Heating Value & $\mathrm{kJ} / \mathrm{kg}$ & Min 40000 & Min 42300 & Min 42300 & Calculated & M07 030 \\
\hline Distillation & $\begin{array}{l}\% \text { at } 250^{\circ} \mathrm{C} \\
\% \text { at } 375^{\circ} \mathrm{C}\end{array}$ & - & $\begin{array}{c}65 \\
\text { Min } 90\end{array}$ & $\begin{array}{c}65 \\
\text { Min } 90 \\
\end{array}$ & $\begin{array}{l}\text { D86 } \\
\text { D86 }\end{array}$ & $\begin{array}{l}\text { M07 } 002 \\
\text { M07 } 002\end{array}$ \\
\hline Flash point & ${ }^{\circ} \mathrm{C}$ & Mini 66 & Mini 66 & Mini 61 & D93 & M07 019 \\
\hline Pour point & ${ }^{\circ} \mathrm{C}$ & Max 15 & Max 15 & - & D97 & T60 105 \\
\hline Ash content & $\% w t$ & Max 0.10 & Max 0.01 & Max 0.01 & D482 & M07 045 \\
\hline Water content & \%wt & $\operatorname{Max} 0.50$ & Max 0.05 & Max 0.05 & D95 & T60 113 \\
\hline $\begin{array}{l}\text { Conradson carbon (on } \\
10 \% \text { distillation residue) }\end{array}$ & $\% w t$ & Max12 & $\operatorname{Max} 0.2$ & $\operatorname{Max} 0.15$ & D189 & T60 116 \\
\hline Aluminium content & ppm & Max 10 & Null & Null & D3682 & - \\
\hline Silicon content & $\mathrm{ppm} \mathrm{SiO} 2$ & Max10 & Null & Null & D3682 & - \\
\hline Sediment content & $\% w t$ & Max 0.05 & $\operatorname{Max} 0.01$ & $\operatorname{Max} 0.01$ & D473 & M07 010 \\
\hline Vanadium content & $\mathrm{ppm}$ & $\operatorname{Max} 150$ & Null & Null & D1548 & M07 027 \\
\hline Sodium content & $\mathrm{ppm}$ & Max 50 & Null & Null & D1548 & M07 027 \\
\hline Sulphur content & $\% w t$ & Max 3 & Max 1.5 & Max 1 & D1551 or D1552 & M07 025 \\
\hline Fluorine content & ppm & Max 10 & Null & Null & D3661 & - \\
\hline Neutralization index & \multirow{3}{*}{$\begin{array}{l}\mathrm{mg} \mathrm{KOH} / \mathrm{g} \\
\mathrm{mg} \mathrm{KOH} / \mathrm{g}\end{array}$} & \multirow{3}{*}{ - } & \multirow{3}{*}{$\begin{array}{c}\text { Null } \\
\text { Max } 3\end{array}$} & \multirow{3}{*}{$\begin{array}{c}\text { Null } \\
\text { Max } 1\end{array}$} & \multirow{3}{*}{ D974 } & \multirow{3}{*}{ - } \\
\hline high acidity & & & & & & \\
\hline low acidity & & & & & & \\
\hline
\end{tabular}

Table 2: Fuel oil specifications in Burkina Faso [80]

\subsection{Biodiesel standards}

Biodiesel is a mixture of fatty acid alkyl esters produced by transesterification of vegetable oil with a short chain alcohol. As biodiesel has a chemical composition relatively close to SVO (alkyl esters versus triglycerides), some of the specifications of the biodiesel standards and of the rapeseed oil pre-standard are the same. To be classified as "biodiesel", the alkyl esters must achieve minimum purity and fulfil the specifications of international standards [82]. There are three main biodiesel standards: the American standard ASTM D6751-09 [83], the European standard EN 14214 [84], and the Brazilian standard ANP N7/2008 [85], the last being largely based on the two others. 
The specifications of these international standards depend on:

i) The predominance of the types of diesel engines most common in the region (larger diesel car fleet in Europe/heavier duty diesel engines in the United States and Brazil)

ii) The atmospheric emission regulations in the region

iii) The nature of the locally available biodiesel feedstock (elaborated to be "feedstock neutral" in Brazil and in the United States, mainly adapted to rapeseed biodiesel in Europe) [86].

Hence the significant differences for the specifications of these three standards, as shown in table 3. Nevertheless, it can be seen that the specifications of the three biodiesel standards (more than 20) can be divided into two main classes [87]: those inspired from diesel specifications (i.e. density, viscosity, flash point, sulphur and sulphated ash content, carbon residue, sediment content, copper strip corrosion, cetane number) and those specific to the biodiesel synthesis process or feedstock. The latter are useful for quantifying residues linked to the feedstock (phosphorus content, $\mathrm{Ca}$ and $\mathrm{Mg}$ contents, acid number, contamination) or to the biodiesel process, i.e. synthesis and purification (glyceride content, glycerol content, alcohol content, ester content, water content, $\mathrm{Na}$ and $\mathrm{K}$ content). It should be noted that some biodiesel specifications related to the quality of the feedstock have also been recommended in the rapeseed oil pre-standard DIN 51605 (see section 4.5.2): $P$ content, $\mathrm{Na}$ and $\mathrm{K}$ content, $\mathrm{Ca}$ and $\mathrm{Mg}$ content, acidity, iodine value, oxidative stability. 


\begin{tabular}{|c|c|c|c|c|c|c|}
\hline Characteristics & Unit & $\begin{array}{c}\text { Limits } \\
\text { ANP N } 7^{\mathrm{a}} / \text { ASTM D6751 }^{\mathrm{b}} / \\
\text { EN } 14214^{\mathrm{c}}\end{array}$ & ABNT NBR ${ }^{a}$ & $\begin{array}{l}\text { Methods } \\
\text { ASTM D }^{b}\end{array}$ & $\mathrm{EN} / \mathrm{ISO}^{\mathrm{C}}$ & $\begin{array}{c}\text { Specifications } \\
\text { source }\end{array}$ \\
\hline Density at $20^{\circ} \mathrm{C}$ & $\mathrm{kg} / \mathrm{m}^{3}$ & $850-900 /-/ 860-900^{a}$ & 7148,14065 & 1298,4052 & $\begin{array}{c}\text { EN ISO } 3675, \text { EN } \\
\text { ISO } 12185\end{array}$ & FDS \\
\hline Kinematic Viscosity at $40^{\circ} \mathrm{C}$ & $\mathrm{mm}^{2} / \mathrm{s}$ & $3.0-6.0 / 1.9-6.0 / 3.5-5.0$ & 10441 & 445 & EN ISO 3104 & FDS \\
\hline Flash point, min. & ${ }^{\circ} \mathrm{C}$ & $100 / 93 / 120$ & 14598 & 93 & EN ISO 3679 & FDS \\
\hline Water and sediment, max & $\%$ vol & $-/ 0.050 /-$ & - & 2709 & - & FDS \\
\hline Carbon residue $100 \%$, max & \% weight & $0.05 / 0.05 / 0.30^{b}$ & 15586 & 4530 & - & FDS \\
\hline $\begin{array}{l}\text { Copper strip corrosion ( } 3 \mathrm{~h} \\
\left.50^{\circ} \mathrm{C}\right) \max \text {. }\end{array}$ & - & class $1 /$ class $3 /$ class 1 & 14359 & 130 & EN ISO 2160 & FDS \\
\hline$(\mathrm{Na}+\mathrm{K})$ content, max. & $\mathrm{mg} / \mathrm{kg}$ & $5 / 5 / 5$ & 15553,15556 & UOP 391 & $\begin{array}{c}\text { EN 14108, EN } \\
14109\end{array}$ & PBF / PBP \\
\hline Ester Content, $\min$ & \% weight & $96.5 /-/ 96.5^{b}$ & 15342 & - & EN 14103 & PBP \\
\hline $\begin{array}{l}\text { Cold Filter Plugging Point, } \\
\text { max. }\end{array}$ & ${ }^{\circ} \mathrm{C}$ & $\begin{array}{c}\text { 19/report/national } \\
\text { specification }\end{array}$ & 14747 & 6371 & EN 116 & FDS \\
\hline Acid number, max. & $\mathrm{mg} \mathrm{KOH} / \mathrm{g}$ & $0.50 / 0.50 / 0.50$ & 14448 & 664 & N 1410, E4 & PBP / PBF \\
\hline Free glycerol max. & \% weight & $0.02 / 0.020 / 0.02^{b}$ & 15341 & 6584 & $\begin{array}{c}\text { EN 14105, EN } \\
14106\end{array}$ & PBP \\
\hline Total glycerol, max. & $\%$ weight & $0.25 / 0.240 / 0.25^{b}$ & 15344 & 6584 & EN 14105 & PBP \\
\hline MG, DG, TG content max & $\% \mathrm{~m} / \mathrm{m}$ & $\begin{array}{c}\text { Report/-/MG } 0.80^{\mathrm{b}} ; \mathrm{DG} \\
0.20^{\mathrm{b}} ; \mathrm{TG} 0.20^{\mathrm{b}}\end{array}$ & 15342,15344 & 6584 & EN 14105 & PBP \\
\hline $\begin{array}{l}\text { Linolenic acid } \\
\text { methylester, } \max \end{array}$ & $\% \mathrm{~mol}$ & $-/-/ 12$ & - & - & EN 14103 & PBF \\
\hline $\begin{array}{l}\text { Polyunsaturated ( } \geq 4 \text { double } \\
\text { bonds) methyl esters, max }\end{array}$ & $\% \mathrm{~mol}$ & $-/-/ 1$ & - & - & EN 14103 & PBF \\
\hline
\end{tabular}

Table 3: Biodiesel specifications

a : Brazilian standard ANP N7/2008 [85], ${ }^{\text {b }}$ : American standard ASTM D6751-09 [83], ${ }^{\mathrm{c}}$ : European standard EN 14214 [84], FDS: From Diesel Specification, PBP: Proper Biodiesel Process, PBF: Proper Biodiesel Feedstock

\subsection{Vegetable oil quality standards}

\subsubsection{History}

The first studies on using vegetable oil in diesel engines were led by Gaupp in 1937 [88] and focused on how the physical properties of various vegetable oils, such as viscosity, pour point, or iodine value, affected diesel engines. The impacts of vegetable oil contaminants on diesel engines (such as water or phosphorus) [89] were not a matter of concern at that time. 
In 1982, during the International Conference on Plant and Vegetable Oils as Fuels, Pryde proposed a first tentative SVO standard [90]. In his study, Pryde found that SVOs did not meet the ASTM 975 specifications for Fuel Oil No. 2. He reported that some analytical methods were not suited to SVO, especially those used for measuring the flash point, $90 \%$ distillation temperature and cetane number. He recommended working on vegetable oil modifications to successfully give them physico-chemical properties compliant with standard No. 2 (dilution, transesterification, preheating, microemulsions) rather than adapting standard No. 2 to SVOs. However, he suggested a tentative standard, with some limit values for several specifications, but also specifying: "vegetable oils must be recognized as experimental fuels. Therefore the suggested specifications for vegetable oils [...] merely serve as a means for determining the quality or even identity of the experimental fuels and do not serve as specifications for fuel use" [90]. Because of the low petroleum oil prices in the 1980s and then the major interest of the United States in biodiesel, the work initiated by Pryde was never carried on.

Shortly thereafter, Germany became the leader in SVO research and proposed in 1994 a draft quality standard for rapeseed oil as a fuel. This proposal was then successfully improved in 1996, then in 2000, to become the Weihenstephan Quality Plan [30]. Finally, the Weihenstephan Quality Plan standard was reviewed in 2006 to become a quality pre-standard, DIN V 51605, for rapeseed oil as a fuel. A commission is currently working on converting pre-standard DIN V 51605 into a final standard DIN 51605 [89]. The evolution of standards from the 1980s to nowadays is summed up in Table 4. The main evolutions concern the phosphorus content, whose limit dropped from 30 to $12 \mathrm{ppm}$ in pre-standard DIN V 51605. Special attention was paid to phosphorus not only because of the formation of deposits that clog injectors and valves, and foul the walls of the combustion chamber, but also because phosphorus is a poison to catalysts used in exhaust mufflers to oxidize unburnt residues. Moreover, the catalysts used in modern diesel engines can be deactivated by earth alkali metals, such as $\mathrm{Ca}$ and $\mathrm{Mg}$, which became important parameters to control in SVOs, and the commission has been working on $\mathrm{Na}$ and $\mathrm{K}$ specifications in the last few years [89, 91].

\subsubsection{Pre-standard DIN V 51605: applicability and limitations}

Pre-standard DIN V51605 is recognized as a reference within the community of people who are interested in using vegetable oil as fuel [92]. Even though the authors state that it is possible to use rapeseed oil as fuel in commercial vehicles and trucks, in all cases they recommend either adapting the engine in a dual-fuel mode with fuel preheating, or using it as a mixture by incorporating rapeseed oil in diesel fuel $[32,91]$.

Nevertheless, this pre-standard DIN V51605 shows some limitations. First of all, the pre-standard is restricted to rapeseed oil. Some specifications, such as the cetane number and kinematic viscosity, are too restrictive and not suited to the physico-chemical properties of SVOs for use in stationary diesel engines. Based on these standard specifications, palm oil cannot be used as fuel, although many stationary engines are already fuelled with that oil [93-96].

Moreover, test methods have not been designed for vegetable oils but for diesel fuels or for biodiesel. Their repeatability and applicability to vegetable oils need to be evaluated [32]. Given the nature of complex mixtures of petroleum-derived products, their characterization methods often require highly specialized analytical tools, which are too sophisticated for the analysis of simple mixtures like vegetable oils. These tools may not be affordable to small certification laboratories in developing countries. Moreover, the 15 parameters recommended in the pre-standard are not necessarily useful in the case of stationary applications. Therefore, in the next section, we will propose specifications that are better suited to stationary applications in terms of parameters, test 
methods and limit values. These specifications will be discussed in relation to the specifications in pre-standard DIN V 51605.

\section{Towards an SVO standard: Parameters, Test methods \& Limit Values}

In pre-standard DIN V 51605 [70], 15 parameters are controlled and a distinction is made between characteristic properties and variable properties (Table 4), which was already made by Pryde et al [90]. The characteristic properties are related to the nature of the feedstock. They are relatively constant for a given kind of oil and even between different oil types (see Table 1). The variable properties (total contamination, water content, phosphorus content, free fatty acid content, ash content, oxidation stability and $\mathrm{Ca}$ and $\mathrm{Mg}$ content) are greatly influenced by the conditions under which seeds are obtained and processed into oil. Indeed these oil properties greatly depend on agronomic factors (seed variety, cultural techniques, climatic conditions, harvesting, etc.), seed storage conditions, processing factors (seed roasting, extraction, filtration, etc.) and oil storage conditions [89].

In this section, we propose 7 crucial parameters selected from the 15 provided by the pre-standard, to be measured for the quality certification of SVOs for stationary applications. For the chosen parameters, the test methods and/or limit values proposed by pre-standard DIN V 51605 are readjusted.

\begin{tabular}{|c|c|c|c|c|c|c|}
\hline & Unit & $\begin{array}{l}\text { E. H. Pryde } \\
(1982)[90]\end{array}$ & $\begin{array}{l}\text { Draft of quality } \\
\text { standard } \\
\text { (1994) [89] }\end{array}$ & $\begin{array}{l}\text { Weihenstephan } \\
\text { Quality Plan } \\
\text { (2000) [30] }\end{array}$ & $\begin{array}{l}\text { Pre-standard } \\
\text { DIN V 51605 } \\
(2006)[70]\end{array}$ & $\begin{array}{c}\text { Test method of Pre- } \\
\text { standard DIN V } 51605 \\
\text { [70] }\end{array}$ \\
\hline \multicolumn{7}{|l|}{ Characteristic features } \\
\hline Specific gravity at $15^{\circ} \mathrm{C}$ & $\mathrm{kg} / \mathrm{m}^{3}$ & $0,91-0,93$ & $0,90-0,93$ & $0,90-0,93$ & $900-930$ & DIN EN ISO 3675/ 12185 \\
\hline lodine value & $\mathrm{g} \mathrm{I}_{2} / 100 \mathrm{~g}$ & $80-145$ & $<115$ & $100-120$ & $95-125$ & DIN EN 14111 \\
\hline Viscosity at $40^{\circ} \mathrm{C}^{*}$ & Cst & $30-50 * *$ & $<80^{*}$ & $<38$ & $<36$ & DIN EN ISO 3104 \\
\hline Flash point, $\min$ & ${ }^{\circ} \mathrm{C}$ & 300 & 55 & 220 & 220 & DIN EN 2719 \\
\hline Carbon residue, $\max$ & $\%(\mathrm{~m} / \mathrm{m})$ & - & 0,5 & 0,4 & 0,4 & DIN EN ISO 10370 \\
\hline Heat value, $\min$ & $\mathrm{kJ} / \mathrm{kg}$ & - & 35000 & 35000 & 36000 & DIN 51900-1, -2, -3 \\
\hline $\begin{array}{r}\text { Combustibility (cetane } \\
\text { number) }\end{array}$ & - & $30-40$ & 39 & - & $>39$ & IP 498 \\
\hline Sulphur content, max & $\mathrm{mg} / \mathrm{kg}$ & - & 300 & 20 & 10 & DIN EN ISO 20884/20846 \\
\hline \multicolumn{7}{|l|}{ Variable features } \\
\hline $\begin{array}{r}\text { Total contamination } \\
\text { (insolubles) max }\end{array}$ & $\mathrm{mg} / \mathrm{kg}$ & 10 & - & 25 & 24 & DIN EN 12662 \\
\hline $\begin{array}{r}\text { Water content Karl Fisher } \\
\max \end{array}$ & $\%(\mathrm{~m} / \mathrm{m})$ & 0,2 & 0,1 & 0.075 & 0.075 & DIN EN ISO 12937 \\
\hline Phosphorus max & $\mathrm{mg} / \mathrm{kg}$ & 200 & 30 & 15 & 12 & DIN EN 14107 \\
\hline Free fatty acid max & $\begin{array}{c}\mathrm{mg} \\
\mathrm{KOH} / \mathrm{g}\end{array}$ & - & 1,5 & 2 & 2 & DIN EN 14104 \\
\hline Ash content max & $\mathrm{mg} / \mathrm{kg}$ & 500 & 200 & 100 & 100 & DIN EN ISO 6245 \\
\hline $\begin{array}{r}\text { Oxidation stability } \min \text { at } \\
110^{\circ} \mathrm{C} \\
\end{array}$ & $\mathrm{h}$ & - & - & 5 & 6 & DIN EN 14112 \\
\hline $\mathrm{Ca}+\mathrm{Mg}$ content, $\max$ & $\mathrm{mg} / \mathrm{kg}$ & - & - & - & 20 & DIN EN 14538 \\
\hline
\end{tabular}

Table 4: Evolution of oil quality standards from 1982 to 2006 *viscosity at $20^{\circ} \mathrm{C} ; * *$ viscosity at $38^{\circ} \mathrm{C}$

\subsection{Selection of the relevant characteristic properties}


As explained earlier, characteristic properties are dependent on the feedstock and constant for a given feedstock. So it is not necessarily relevant to measure all these parameters to characterize the behaviour and quality of SVOs, unless to attest the origin and the purity of the vegetable oil, i.e. the fact that it has not been mixed with other products.

\subsubsection{Discarded characteristic properties}

The flash point of a fuel is an important safety storage and handling parameter and does not influence the performance of the engine [13]. The flash point of vegetable oils is sufficiently high (over $220^{\circ} \mathrm{C}$, except for babassu oil $150^{\circ} \mathrm{C}$, while over $66^{\circ} \mathrm{C}$ for diesel oil) to ensure good handling safety [97], so it is not necessary to measure it. Moreover, the closed cup distillation method, DIN EN 2719 , proposed by the pre-standard is not applicable.

The carbon residue of diesel fuel correlates approximately with combustion chamber deposits which relate to the lifetime of a diesel engine. After filtration or degumming processes, the rate of carbon residue $[35,98]$ ranges from $0.2 \% \mathrm{wt}$ to $0.3 \% \mathrm{wt}$, which remains below the maximum value limit of $0.4 \%$ wt given by the pre-standard specifications [99].

The higher heating value of vegetable oil is a measurement to assess its energy content. The higher heating values of oils are slightly variable from one to another $(36-40 \mathrm{MJ} / \mathrm{kg}$ ) but higher than the prestandard limit value of $36 \mathrm{MJ} / \mathrm{kg}$ for all of them (Table 1). Therefore, there is no special need to analyse the higher heating value, except to calculate rates of substitution, when no values are available or have been found in the literature.

The cetane number is relatively constant within a kind of vegetable oil and even between different kinds of oils (35-45) (Table 1). Therefore, measurement of the cetane number to ensure good quality SVO in stationary engines is pointless.

Vegetable oil sulphur content is generally close to zero and lower in any event than that of diesel fuels $(\leq 100 \mathrm{ppm})[28,100]$. While the specifications for light diesel are fixed at around $10-15 \mathrm{ppm}$ in Europe [101], this limit is much higher in other countries and reaches $500 \mathrm{ppm}$ in India [28], 5,000 ppm in the USA and 10,000 ppm in Burkina Faso. The sulphur content specifications for heavier fuel oils are even higher (30,000 ppm in Burkina Faso) (see Table 2). For these reasons, the assessment of sulphur content in vegetable oils for use in stationary engines is not compulsory.

\subsubsection{Chosen characteristic properties}

It is essential to measure three characteristic parameters to ensure that the fuel used is indeed pure vegetable oil and to confirm the vegetable origin: density, viscosity and iodine value.

The density specification is suitable for excluding material other than vegetable oil, or for detecting mixtures of vegetable oil with other liquids (petroleum products, glycerol, etc). The density of vegetable oils is slightly variable between 900 and $960 \mathrm{~kg} / \mathrm{m}^{3}$ (Table 1). It is higher than that of diesel and DDO $\left(<900 \mathrm{~kg} / \mathrm{m}^{3}\right.$ in Burkina Faso) and slightly lower (about 9\%) than that of Fuel Oil 180 (920$990 \mathrm{~kg} / \mathrm{m}^{3}$ in Burkina Faso). Nevertheless, the limit value proposed in pre-standard DIN V 51605 (900$930 \mathrm{~kg} / \mathrm{m}^{3}$ ) should be extended from 900 to $960 \mathrm{~kg} / \mathrm{m}^{3}$, so as not to exclude vegetable oils such as castor, jatropha, mahua, neem, or babassu oil. The test method by gravimetry, ISO 6883, used for edible oils is very simple to handle.

Moreover, it is relevant to control density as a fuel pump is a volumetric device. So, for the same $\mathrm{HHV}$, a fuel with a low density implies that the energy content per unit of volume decreases, which results in a lower fuel-air equivalence ratio inside the combustion chamber and a decrease in the energy delivered per cycle [58]. Consequently, for a fuel with a high density, although this increases 
the energy delivered per cycle, the excess fuel-air equivalence ratio inside the combustion chamber results in an increase in unburnt fuel and particle emissions in the exhaust gases.

Viscosity is a rapid indicator of fuel quality before use, especially if the nature of the feedstock is not well known, or if the oil could have been deteriorated or polymerized during storage [102]. As explained in section 3.2.1, the kinematic viscosity of SVO is higher than that of conventional grade No. 2-D diesel fuel, but lower than that of heavy fuel oil. Even though it is recommended to preheat SVOs, to reduce their viscosity, it needs to be ensured that the elements of the pump are robust enough to circulate this liquid [58]. Indeed, the use of high-viscosity fuels lowers the efficiency of the injection pump, shortens the lifespan of a pump and increases the risk of fuel leakage. In all cases, it is preferable to ensure that the pump is capable of withstanding at least viscosities above $100 \mathrm{cSt}$. This value is recommended by the engine manufacturer Wartsila, which has installed several hundred MW power plants running on SVO mainly produced from palm oil in Italy [103].

Test method ISO 3104 in pre-standard DIN V 51605 is suitable for an SVO standard for stationary engines. However, the limit value may be increased from 25 to $50 \mathrm{cSt}$ to include a wider range of vegetable oils such as castor oil, palm oil or peanut oil. Special attention should be paid to some saturated oils (palm oil, coconut oil, babassu oil, fats) which are solid at low temperatures (Table 1) and must be preheated, especially in fuel tanks and lines [90]. The problems linked to low temperatures are less a matter of concern in tropical countries, such as in West Africa.

The iodine value is a measurement of the total unsaturation of vegetable oils, as well as an indicator of their susceptibility to oxidation [102]. Vegetable oils can be divided into four major categories depending on their iodine value: saturated oils (iodine value between 5 and 50), so-called semi-siccative mono-unsaturated oils (50 and 100), di-unsaturated oils, also called semi-siccative (100 and 150) and tri-unsaturated oils called siccative (over 150). As shown in figure 3, this parameter is specific to each oilseed, making it possible to check the nature of the biomass used. Although SVO viscosity increases with total unsaturation, the iodine value is not a parameter that can be used to draw conclusions about the quality of SVO or the potential presence of impurities [104]. For biodiesel standards, there is some controversy about the need for an iodine value standard at all, and some standards, like ASTM, do not include an iodine value specification [105]. So, contrary to the pre-standard DIN V 51605 specifications, we suggest not setting specific limit values for this parameter, but only reporting it in the analysis report. The iodine value test method proposed in prestandard DIN V 51605, the Wijs analytical method, is suitable for biodiesel (known as EN 14111) and vegetable oils (known as ISO 3961) and is adopted for the SVO standard for stationary engines. 


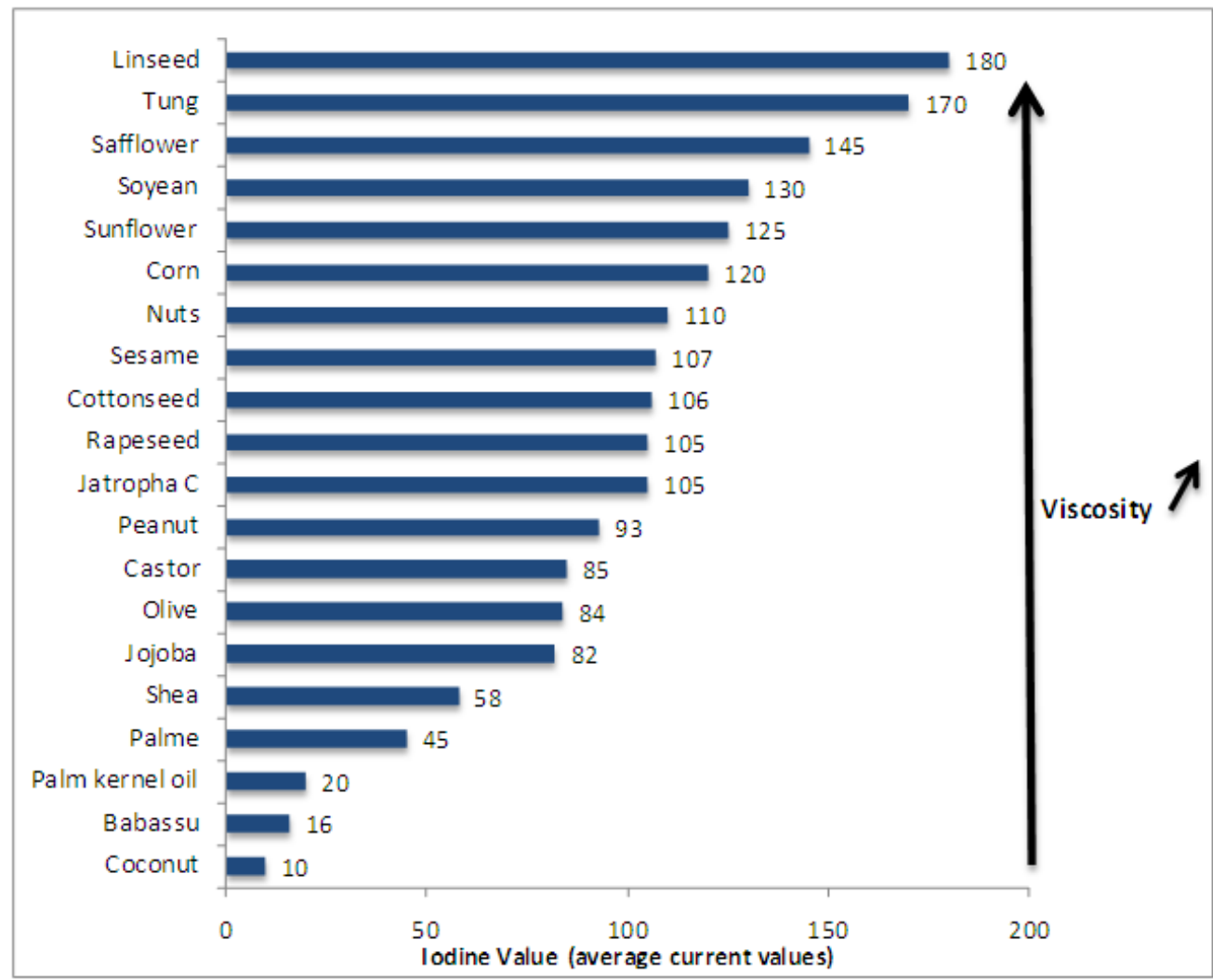

Figure 3: Mean iodine values of different vegetable oils, (viscosity increases with the degree of unsaturation )

\subsection{Selection of the relevant variable properties}

Variable properties are related to the conditions under which SVO is obtained. They can highlight the presence of contaminants and impurities that might lead to engine breakdowns.

\subsubsection{Discarded variable properties}

Ash content indicates the content of minerals and oxides of an abrasive nature for the engine. According to Espadafor and al. [58] ash constituents, such as vanadium, nickel, sodium, aluminium and silicon are harmful for the engine, and their presence merely increases engine wear and corrosion. Moreover, the sticking temperature of the mixture of oxides and vanadium may also cause deposits in the exhaust gas system. Nevertheless, ash is not troublesome because there is 10 to 20 times less ash in SVOs than in petroleum products and it is always recommended to carry out safety filtration before injecting the oil into the combustion chamber. According to most published work, although the initial ash content of crude vegetable oil is about $300-2,300$ ppm, it drops systematically to under $100 \mathrm{ppm}$ when the oil is filtered $[28,106]$.

As all SVO production processes require filtration, the ash content should always be below the limit of 100 ppm specified by both pre-standard DIN V 51605 and SONABHY. It is therefore not necessary to systematically analyse it. If it is feared that SVO may have been contaminated after filtration during transportation, handling or storage, any additional mineral could not dissolve and would be directly detected by measuring total contamination (see 5.2.2)

Oxidative stability is a major issue for the storage of vegetable oils, especially if the oil contains high levels of polyunsaturated fatty acids (PUFA). These PUFA could polymerize into insoluble particles such as gums, sediments or other deposits under the action of light, high storage temperature, or oxygen [104, 107]. However, oxidative stability is closely related to the iodine value [102], which is a 
global measurement of total SVO unsaturation (see section 5.1.2). Moreover, the recommended oxidative stability test methods of European standards (RANCIMAT method specified in EN 14112 [108]) and American standards (Oil Stability Index OSI [109]), are controversial because they are accelerated methods and they are performed at high temperatures, which do not reflect true oil oxidation conditions, as it often occurs at room temperature. Consequently, in order to determine whether SVO has oxidized during improper storage, determination of the free fatty acid content is sufficient, and in order to estimate SVO oxidative stability, measurement of the iodine value should be preferred.

The presence of $\mathbf{C a}$ and $\mathbf{M g}$ in exhaust gases can poison catalytic converters, reducing the benefits for the environment and for human health [32]. In West Africa, there are no sub-regional texts related to air pollution [110]. Only Ivory Coast, Togo, Senegal, Burkina Faso and Benin have an environmental code in which some laws and regulations govern air pollution [111]. However, even for these countries, standards are often not specified and, if specified, monitoring remains an issue [111]. So, as environmental standards in the countries of West Africa have little or no binding power in terms of unburnt releases into the atmosphere, the stationary engines that are sold are not equipped with catalytic converters. Consequently, $\mathrm{Ca}$ and $\mathrm{Mg}$ contents have not been adopted in the proposed standard for vegetable oil as a fuel in stationary engines.

\subsubsection{Chosen variable properties}

The major variable properties that should be measured to ensure sufficient vegetable oil quality for use in stationary engines are the phosphorus content, total contamination, the water content and the free fatty acid content (see table 5).

\begin{tabular}{|c|c|c|c|c|}
\hline & Fuel & Standard & Limit value & Test Method \\
\hline \multirow{3}{*}{ 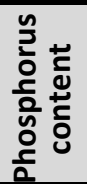 } & Biodiesel & $\begin{array}{c}\text { ANP 42/EN } \\
\text { 14214/ASTM D } 6751\end{array}$ & 10 ppm max & \multirow{2}{*}{$\begin{array}{l}\text { EN 14107/ASTM D4951 } \\
\text { (ICP-OES) }\end{array}$} \\
\hline & \multirow{2}{*}{$\begin{array}{l}\text { Vegetable oil } \\
\text { as a fuel }\end{array}$} & EU DIN V 51605 & $12 \mathrm{ppm} \max$ & \\
\hline & & $\begin{array}{l}\text { Proposed pre-standard } \\
\text { for stationary engines }\end{array}$ & 50 ppm max & $\begin{array}{l}\text { ISO } 10540-1: 2003 \text { (edible oils) } \\
\text { colorimetric method }\end{array}$ \\
\hline \multirow{5}{*}{ 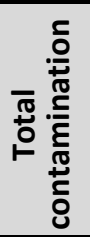 } & Biodiesel & EN 590/ EN 14214 & 24 ppm max & EN ISO 12662 \\
\hline & Diesel/ DDO & SONABHY & 100 ppm max & \\
\hline & Fuel Oil & Burkina Faso & 500 ppm max & 3/AFNOR M07010 \\
\hline & \multirow[b]{2}{*}{$\begin{array}{l}\text { Vegetable oil } \\
\text { as a fuel }\end{array}$} & EU DIN V 51605 & 24 ppm max & DIN EN 12662 \\
\hline & & $\begin{array}{l}\text { Proposed pre-standard } \\
\text { for stationary engines }\end{array}$ & 100 ppm max & $\begin{array}{l}\text { ISO } 663 \text { (edible oils from } 5 \text { to } \\
200 \text { ppm) }\end{array}$ \\
\hline \multirow{5}{*}{ 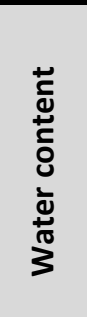 } & \multirow[b]{2}{*}{ Biodiesel } & EN 590/ EN 14214 & 500 ppm max & EN ISO 12937 \\
\hline & & $\begin{array}{c}\text { Water and sediment } \\
\text { ASTM D975/ASTM D6751 }\end{array}$ & 500 ppm max & ASTM D2709 \\
\hline & Diesel/DDO & SONABHY & $500 \mathrm{ppm}$ max & \multirow{2}{*}{ ASTM D95/ AFNOR T60 113} \\
\hline & Fuel Oil & Burkina Faso & $5000 \mathrm{ppm} \max$ & \\
\hline & $\begin{array}{l}\text { Vegetable oil } \\
\text { as a fuel }\end{array}$ & $\begin{array}{l}\text { Proposed pre-standard } \\
\text { for stationary engines }\end{array}$ & 750 ppm max & ISO 8534 (edible oils) \\
\hline \multirow{5}{*}{ 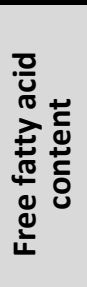 } & Biodiesel & $\begin{array}{c}\text { ANP42/EN 14214/ASTM } \\
\text { D6751 }\end{array}$ & $0.50 \mathrm{mg} \mathrm{KOH} / \mathrm{g}$ & $\begin{array}{l}\text { EN 14104/EN14104/ASTM } \\
\text { D664 }\end{array}$ \\
\hline & Diesel & SONABHY & $1 \mathrm{mg} \mathrm{KOH} / \mathrm{g}$ & \multirow{2}{*}{ D974 } \\
\hline & DDO & SONABHY & $3 \mathrm{mg} \mathrm{KOH} / \mathrm{g}$ & \\
\hline & \multirow[b]{2}{*}{$\begin{array}{l}\text { Vegetable oil } \\
\text { as a fuel }\end{array}$} & EU DIN V 51605 & $2 \mathrm{mg} \mathrm{KOH} / \mathrm{g}$ & EN 14104 \\
\hline & & $\begin{array}{l}\text { Proposed pre-standard } \\
\text { for stationary engines }\end{array}$ & $3 \mathrm{mg} \mathrm{KOH} / \mathrm{g}$ & ISO 660 (edible oils) \\
\hline
\end{tabular}

Table 5: Variable property specifications for different fuels 
The phosphorus content indicates the presence of phospholipids (or mucilage), which are undesirable constituents that come from the cell membranes of seeds and kernels. It is an essential concern in the quality of vegetable oil as a fuel, as using oil with a high level of phospholipids results in the formation of deposits, which coke in hot engine sections (combustion chamber and nozzle holes) [13, 98]. All publications are unanimous on the negative effect of phospholipids, but some researchers attribute the formation of deposits to phenomena taking place within the engine and others to the accumulation in the combustion chamber and nozzles of particles formed during storage, due to the presence of phospholipids [112]. Moreover, as for $\mathrm{Ca}$ and $\mathrm{Mg}$, phosphorus is a poison for the catalysts used to reduce exhaust gas emissions [86, 102], which explains why international standards for biodiesel take it into consideration. But as for $\mathrm{Ca}$ and $\mathrm{Mg}$, this is not a matter of concern for countries in West Africa (see section 5.2.1)

The phosphorus content of seeds mainly depends on the process (expeller temperature) [30], but it is also highly variable from one species to another [113]. For example, it can reach $70 \mathrm{ppm}$ for sunflower oil [106], 200 ppm for jatropha oil [114], 270 ppm for crude soybean oil and $620 \mathrm{ppm}$ for crude cotton oil [106]. Current technical equipment used to filter oils in small-scale oil mills is not able to reduce the phosphorus content. If the phosphorus content is high, it is known from the literature that bleaching earths $[44,115,116]$ and other substances, such as diatomaceous earths $[44,117]$, cellulose $[44,117]$ and synthetic silica gels $[44,115,116]$, are suitable for eliminating phosphorus from vegetable oils. The addition of acid (citric acid or phosphoric acid) and water to oil enables phospholipids to be removed after oil filtration [41, 44].

The pre-standard for vegetable oil proposed ICP-OES (inductively coupled plasma optical emission spectrometry) as a test method for determining phosphorus content, similarly to biodiesel standards. ICP-OES is very complex and expensive. An alternative method, molecular absorption spectrophotometry, based on the formation of blue-coloured molybdenum complexes, was normalized for P content determination in edible oils (ISO 10540-1:2003) [118] and was tested with biodiesel samples by Silveira et al [119]. In that work, visible spectrophotometry proved to have many advantages over ICP-OES, namely simplicity, accuracy, precision and low cost. Moreover, this method has been applied to P content determination in canola oil [120]. It is adopted for the proposed standard for vegetable oil as a fuel in stationary engines.

The first specifications on phosphorus content for SVO were set at $200 \mathrm{ppm}$ [90]. With the development of catalytic converters to reduce vehicle exhaust emissions, recent specifications have lowered the phosphorus thresholds from $15 \mathrm{ppm}$ to $12 \mathrm{ppm}$ in pre-standard DIN V 51605 for vegetable oil (Table 5) and to $10 \mathrm{ppm}$ for biodiesel [83-86]. However, stationary engines (almost) never work with catalytic systems in West Africa. Therefore, the threshold of $12 \mathrm{ppm}$ seems irrelevant and too strict for the standard that we propose for West Africa. A study conducted in 2003 in Germany showed that when pressing conditions were well mastered $\left(<50^{\circ} \mathrm{C}\right)$, the phosphorus content could easily drop below 50 ppm [91] and Vaitilingom showed in his work that a phosphorus content under $50 \mathrm{ppm}$ in vegetable oil is sufficient to have the qualities required for fuel use [45]. For these reasons, the phosphorus threshold could be set at $50 \mathrm{ppm}$ for SVO use in stationary engines.

Total contamination is defined as the insoluble solid particles that are retained after fuel filtration. Even though vegetable oil particles are less abrasive than the mineral particles found in petroleum products [58], they must be limited, as a high level of contamination can block filters and nozzles, and they are also abrasive for the pump and injection system. Contamination can also be reduced by proper filtration of the vegetable oil at $5 \mu \mathrm{m}$, as recommended in the fuel quality standard proposed 
in 1994 [89]. Test method EN 12662 proposed by pre-standard DIN V 51605 is the same as for diesel fuel and biodiesel with an extraction thimble of $0.8 \mu \mathrm{m}$ porosity [30]. However, this method applies to liquid petroleum products with a low kinematic viscosity $\left(<5 \mathrm{cSt}\right.$ at $\left.40^{\circ} \mathrm{C}\right)$ [102] and is not suitable for vegetable oils. We therefore suggest ISO 663 [121], originally used for edible oil analysis.

In biodiesel standards, the limit value for total contamination has been set at $24 \mathrm{ppm}$. The presence of these abrasive materials (that mainly come from catalysts) in higher concentrations can shorten filter and pump life or clog fuel filters, which can lead to engine fuel starvation [122]. In pre-standard DIN V 51605, the same limit value of 24 ppm was adopted. However, in West Africa, fuel standards specify 100 ppm as the limit value for total contaminants in both diesel and DDO.

Total contamination is highly variable, depending on the seeds and the process. Some studies report very high contamination in crude unfiltered jatropha oil (around 30\%) compared to that of rapeseed oil (5\%) [114]. Because of its variability, this parameter must be absolutely controlled. Indeed, particles were the major problem encountered in 31 decentralized oil mills in 2003 [29]. Even in rapeseed oil, the limit value of $24 \mathrm{ppm}$ was virtually not achieved in most of the decentralized rapeseed oil mills that were evaluated $[29,91]$. Half of the tested samples had a total contamination exceeding 24 ppm, though it remained below 60 ppm for $90 \%$ of the samples.

Based on these technical arguments, regarding the limit value of $100 \mathrm{ppm}$ for total contamination for both diesel and DDO in West Africa, and the lower abrasivity of SVO particles than petroleum product particles [58], we suggest fixing the total contamination limit value for SVO in stationary engines at $100 \mathrm{ppm}$.

Water content is limited in fuel specifications because it promotes microbial growth, tank and filter corrosion, and hydrolysis that leads to fatty acid formation. During combustion, if water is well emulsified in SVO, the effective energy content of the fuel decreases, leading to increased fuel consumption. Depending on the water concentration, in the long term it causes cavitation events in the combustion chamber. In the case of SVO or biodiesel, water can induce phase separation if blended with diesel [86]. The ISO 12937 test method, coulometric Karl-Fischer titration, was proposed in the diesel and biodiesel standards and in the SVO pre-standard DIN V 51605. This Karl Fisher method, also proposed for edible oils as ISO 8534, has been selected for water content determination in SVO. It is easy to perform, even though some stabilization problems, due to high relative humidity, can be encountered during the rainy season in tropical countries.

The water content of crude and refined vegetable oils can reach 600-1200 ppm in some cases [106]. The specifications for fuel oil in West African countries are 500 ppm, so lower than those proposed in the German pre-standard of 750 ppm. Nevertheless, for use in stationary diesel engines, the limit value in pre-standard DIN V 51605 can be reasonably maintained at 750 ppm, as it is much lower than the 5,000 ppm specified for heavy fuels [58].

Acidity in vegetable oils can vary from $0.01 \%$ to $10 \% \mathrm{wt}$ (which corresponds to 0.02 to $20 \mathrm{mg} \mathrm{KOH} / \mathrm{g}$ oil) $[37,106]$. Free fatty acids have smaller molecular weights than the triglycerides they are derived from, which makes acidic vegetable oils more easily flammable. According to Vaitilingom, the free fatty acids of SVO are not a problem for use in diesel engines up to $10 \% \mathrm{wt}$. When acidity increases from $0.01 \%$ to $1 \% \mathrm{wt}$, and to $10 \% \mathrm{wt}$, the "flash point" is reduced by $20^{\circ} \mathrm{C}$ and $85^{\circ} \mathrm{C}$ respectively [37]. However, free fatty acids cause corrosion and deposits in the engine. In fact, free fatty acids are markers of vegetable oil quality, as they are generated during the process as well as during ageing. The free fatty acid content must be carefully controlled to monitor fuel quality, especially since it is a 
simple parameter to measure [102]. The test method EN 14104 proposed in fuel standards (biodiesel standards, pre-standard DIN V 51605, EN ISO 660 for edible oil), is titration using an ethanolic $\mathrm{KOH}$ solution with phenolphthalein as an indicator. This test method can be adopted in the SVO standard for stationary engines. Despite the fact that some engine manufacturers, such as Wartsila, accept free fatty acid contents up to $15 \mathrm{mg} \mathrm{KOH} / \mathrm{g}$ SVO, acidity is responsible for damage to engine feed circuits (hose, gasket, etc.) and engine corrosion [37, 60]. As set for DDO in West African countries, the limit value proposed in the standard for stationary engines is $3 \mathrm{mg} \mathrm{KOH} / \mathrm{g}$ oil (which is higher than the $2 \mathrm{mg} \mathrm{KOH} / \mathrm{g}$ in pre-standard DIN V 51605).

\begin{tabular}{|c|c|c|}
\hline Parameter & Test method & Equipment investment \\
\hline $\begin{array}{l}\text { Kinematic Viscosity } \\
\text { at } 40^{\circ} \mathrm{C}\end{array}$ & ISO 3104 & $\begin{array}{c}\text { Falling-ball viscometer }+ \\
\text { thermostatically controlled water } \\
\text { bath }=€ 5,000\end{array}$ \\
\hline $\begin{array}{l}\text { Specific gravity at } \\
15^{\circ} \mathrm{C}\end{array}$ & ISO 6883 [126] & $\begin{array}{c}\text { Pycnometer }+ \text { precision balance }= \\
€ 2,650\end{array}$ \\
\hline lodine value & ISO 3961 [127] & $\begin{array}{l}\text { Burette }+ \text { burette stand }+ \\
\text { magnetic stirrer }=€ 450\end{array}$ \\
\hline Free fatty acid & ISO 660 [126] & Ditto iodine value \\
\hline $\begin{array}{l}\text { Total contamination } \\
\text { (insolubles) }\end{array}$ & ISO 663 [121] & $\begin{array}{l}\text { Filtering funnel (porosity } 3 \text { ) + oven } \\
+ \text { suction flask + oven +vacuum } \\
\text { pump }=€ 2,200\end{array}$ \\
\hline Water content & $\begin{array}{c}\text { ISO 8534-Karl Fisher } \\
\text { method [128] }\end{array}$ & $\begin{array}{l}\text { Karl Fischer coulometric } \\
\text { titrator }=€ 4,500\end{array}$ \\
\hline Phosphorus & $\begin{array}{c}\text { ISO 10540-1:2003- } \\
\text { Colorimetric } \\
\text { method [129] }\end{array}$ & $\begin{array}{c}\text { Silica crucible }+ \text { visible } \\
\text { spectrophotometer }+ \text { muffle } \\
\text { furnace }=€ 4,300\end{array}$ \\
\hline
\end{tabular}

Table 6: Estimation of investment cost to set up a laboratory to analyse /characterise vegetable oil as a fuel in stationary engines

\section{Discussion}

It can be seen that it is essential to propose quality criteria to be analysed for SVO use as fuel. Even though the extraction of SVOs from oil-bearing biomass and their use as engine fuels are simple from a technical point of view, it is absolutely necessary to check oil quality so as not to damage the engine. Whilst the choice of the seven parameters to be controlled was mainly based on existing standards, it was also motivated by the requirements of engine manufacturers, who have huge experience of running engines on SVOs. SVOs are already widely used for power generation, for example with Wartsila engines [103]. Such engine manufacturers specialized in SVO use have shown that stationary engines can run on vegetable oil, without needing to convert it into biodiesel. It is sufficient to adapt the engine with a dual-fuel system, which ensures 1 ) that the combustion chamber of the engine is hot enough to achieve complete combustion of the oil and 2) that the oil is sufficiently fluid to be pumped and injected into the engine. Engine manufacturers have various recommendations regarding SVO quality. Elsbett [123], which markets engines that can operate on vegetable oil without modifications, specifies the parameters related to oil quality that it is important 
to check. On its website, the manufacturer recommends: "a rough oil quality check should mainly be focused on three variable properties: 1) Contamination, 2) Phosphorus Content and 3) Water Content [123]. Wartsila proposes a full set of specifications with 20 different parameters to control [103]. In our proposed standard for vegetable oil as a fuel in stationary engines, we also recommend measuring the free fatty acid content and viscosity using simple, cheap and rapid analytical methods, in order to guarantee that the injection system (tank, pump, filters, hoses, injector, etc.) will not be damaged in the long run. Moreover, if any doubts exist about the quality of the oil, or if the obtained kinematic viscosity values are not in agreement with those given in the literature, or are off limits compared to the standard, measurement of the iodine value and/or density of the oil are also recommended, to ensure its origin and/or purity.

As the design and working conditions of stationary engines are different from those of vehicle engines, pre-standard DIN V51605 appears too restrictive and, for a few parameters, even appears not to be applicable to SVO. Its promotion for stationary engines would lead to higher fuel costs and, in most cases, to the banning of SVO.

Table 7 summarises the set of parameters, thresholds and test methods suggested for applications in stationary engines not fitted with catalytic converters West Africa.

This proposal was motivated by technical arguments but also by practical and economic considerations.

The standard to be proposed must involve analytical techniques that are cheap, simple to carry out with conventional laboratory equipment and quick to perform, so as to be accessible as widely as possible to quality control laboratories in Africa. Such a pre-standard is essential if the use and trading of vegetable oils as fuels is to develop.

Based on equipment prices when purchased in Europe and imported into West Africa (see Table 6), we estimate that the cost of setting up a properly equipped laboratory to implement this standard certification would be around $€ 19,000$. From $2 \mathrm{iE}$ laboratory experience, considering the purchase of required reagents, solvents and standards (for equipment calibration), the cost for one set of analyses ( 2 replications) amounts to $€ 47.5$, excluding depreciation and maintenance costs, which would greatly depend on the number of analyses carried out per year. Thus, according to our simulations, and depending on the number of samples to be analysed, one set of the 7 recommended analyses would cost from $€ 60$ to $€ 100$. Comparing these figures to SVO selling prices, which vary from 75 to 100 cents per litre [124], it remains clear that such quality control costs would only remain accessible for relatively large-scale applications. 


\begin{tabular}{|c|c|c|c|c|c|c|}
\hline \multirow{2}{*}{ PARAMETER } & \multirow{2}{*}{ UNIT } & \multirow{2}{*}{$\begin{array}{c}\text { TEST } \\
\text { METHOD }\end{array}$} & \multirow{2}{*}{ METHOD OF ANALYSI, } & \multirow{2}{*}{ PRINCIPLE } & \multicolumn{2}{|c|}{ LIMITE VALUE } \\
\hline & & & & & MIN & MAX \\
\hline $\begin{array}{c}\text { SPECIFIC GRAVITY } \\
\text { AT } 15^{\circ} \mathrm{C}\end{array}$ & $\mathrm{Kg} / \mathrm{m}^{3}$ & ISO 6883 & Pycnometry & $\begin{array}{l}\text { At } 15^{\circ} \mathrm{C} \text { measurement of the mass before } \\
\text { and after filling of the pycnometer with the } \\
\text { sample. }\end{array}$ & 0,90 & 0.96 \\
\hline $\begin{array}{c}\text { KINEMATIC } \\
\text { VISCOSITY AT } 40^{\circ} \mathrm{C}\end{array}$ & Cst & ISO 3104 & $\begin{array}{l}\text { Falling ball } \\
\text { viscometer }\end{array}$ & $\begin{array}{l}\text { Measuring the time of the fall of a ball } \\
\text { subjected to gravity in an inclined tube filled } \\
\text { with the sample product and preconditioned } \\
\text { at } 40^{\circ} \mathrm{C}\end{array}$ & \multicolumn{2}{|c|}{50} \\
\hline IODINE VALUE & $\mathrm{g} \mathrm{I}_{2} / 100 \mathrm{~g}$ & ISO 3961 & $\begin{array}{l}\text { Extraction - } \\
\text { titrimetry }\end{array}$ & $\begin{array}{l}\text { Preparation of a sample solution in a solvent } \\
\text { mixture and then titrating with Wij's reagent }\end{array}$ & \multicolumn{2}{|c|}{ Report } \\
\hline PHOSPHORUS MAX & ppm & $\begin{array}{c}\text { ISO } \\
10540-1\end{array}$ & $\begin{array}{l}\text { Calcination- } \\
\text { spectrocolorimetry }\end{array}$ & $\begin{array}{l}\text { - Calcination of a sample, then nitric acid } \\
\text { attack of the remaining ash } \\
\text { - Formation of a yellow phosphovanado- } \\
\text { molybdate complex after reaction between } \\
\text { phosphoric ions / molybdic and vanadic ions } \\
\text { - Quantification of the intensity of the yellow } \\
\text { colour obtained using the spectrophotometer } \\
\text { to evaluate the phosphorus content }\end{array}$ & \multicolumn{2}{|c|}{50} \\
\hline $\begin{array}{l}\text { FREE FATTY ACID } \\
\text { MAX }\end{array}$ & $\mathrm{mg} \mathrm{KOH} / \mathrm{g}$ & ISO 660 & $\begin{array}{l}\text { Extraction - } \\
\text { titrimetry }\end{array}$ & $\begin{array}{l}\text { Dissolution of a test in a mixture of solvent } \\
\text { and titration of free fatty acids with an } \\
\text { ethanol solution of potassium hydroxide }\end{array}$ & \multicolumn{2}{|c|}{3} \\
\hline $\begin{array}{c}\text { TOTAL } \\
\text { CONTAMINATION } \\
\text { (INSOLUBLES) MAX }\end{array}$ & ppm & ISO 663 & Gravimetry & $\begin{array}{l}\text { Treating the product with an excess of } \\
\text { solvent, filtering the solution, washing the } \\
\text { residue with the same solvent and drying at } \\
103^{\circ} \mathrm{C} \pm 2^{\circ} \mathrm{C} \text { to constant weight. }\end{array}$ & \multicolumn{2}{|c|}{100} \\
\hline WATER CONTENT & ppm & ISO 8534 & $\begin{array}{c}\text { Coulometric titration } \\
\text { (Karl Fischer) }\end{array}$ & $\begin{array}{l}\text { Reaction between water, iodine and sulphur } \\
\text { dioxide in the presence of methanol and } \\
\text { pyridine- Electronic end point determination }\end{array}$ & \multicolumn{2}{|c|}{750} \\
\hline
\end{tabular}

Table 7: Proposed standard specifications for vegetable oil as a fuel in stationary engines

\section{Conclusions}

In order to meet the growing demand for energy in West African countries and to cope with the craze in that region for biofuels from oil-bearing plants, it has become necessary to develop a standard that allows easy testing of the quality of a vegetable oil for fuel use. Due to their physicochemical characteristics, in particular their high viscosity and low cetane index, vegetable oils as fuels have properties that are similar to those of Heavy Fuel Oils, which are commonly used in West Africa. Combustion problems inherent to the high viscosity and low cetane index of vegetable oils can be easily overcome, either by using SVOs blended with diesel at a low oil content, or by adapting engines with a dual-fuelling system. However, although these simple technical options enable easy operation of stationary engines with SVO, it is absolutely necessary to ensure that the vegetable oils used do not contain impurities, which could quickly damage the engine, either in the combustion chamber or in all of the peripheral fuel supply and exhaust gas devices. Given the number of operators involved in SVO production in West Africa, biofuels from diverse origins will soon be traded and used. Consequently, oil quality is a recurring issue and its proper management is a key success factor for the development of the biofuel sector. Based on 1) a critical review of existing standards for various diesel engine fuels and 2) on the current knowledge of vegetable oil characterization, we 
propose a basic set of quality criteria that SVOs must comply with, in order to fuel stationary diesel engines without causing breakdowns or serious lifetime reductions

This pre-standard specifies the measurement of 7 parameters, two of which are recommended but not necessarily compulsory. The specifications of this pre-standard recommend analytical methods that are easy and inexpensive to implement. The limit values suggested match the targeted type of vegetable oil use, i.e. stationary diesel engines for non-vehicle applications. As such engines are heavy duty and operate under more stable conditions than vehicle engines, the proposed standard is less strict than that for standard diesel fuels (diesel and biodiesel).

The specifications proposed by this pre-standard will have to be validated in the coming years, especially:

i) Methods must be tested in the 2iE laboratory for different types of vegetable oils available in West Africa and re-adapted according to the different contaminant contents,

ii) Limit values for the specified contaminants must be tested in the field by long-run tests on some engines in thermal power plants.

The West African Economic and Monetary Union (WAEMU), which is convinced of the need to harmonize standards in its member countries to promote trade and encourage exchanges between the countries, wishes to provide impetus to such an initiative in its zone of influence. This work will make it possible to validate the pre-standard, and then it will serve as a basis for further deliberation by a working group for a standardization process within WAEMU.

As the rough cost analysis shows, these costs, while being minimised, remain inaccessible for smallscale applications (few dozen kW). Consequently, 2iE is also working on a simplified methodology to guarantee safe use of SVO in stationary engines associated with a specific engine maintenance methodology.

\section{Acknowledgements}

This work was undertaken with the assistance of the European Union. Its content is the exclusive responsibility of the authors and does not represent the point of view of that institution. 


\section{References}

[1] Roudardt L. Terres cultivables non cultivées : Des disponibilités suffisantes pour la sécurité alimentaire durable de l'humanité. Centre d'etudes et de prospective , Analyse 2010;18

[2] Klaus D, Derek B. Rising Global Interest in Farmland: Can It Yield Sustainable and Equitable Benefits. World Bank 2010.

[3] Blein R, Goura Soulé B, Faivre Dupaigre B, Yérima B. Les potentialités agricoles de l'Afrique de I'Ouest (CEDEAO). FARM; 2008.

[4] Roudart L. Terres cultivables et terres cultivées : Rapport de l'analyse croisée de trois bases de données à l'échelle mondiale. Notes et études socio-économiques. 2010 34:57-95.

[5] Azoumah Y, Blin J. R \& D sur les biocarburants en Afrique de l'Ouest : état des lieux et enjeux Liaison Énergie-Francophonie. 2009;82:15-20.

[6] Blin J, Dabat M-H, Faugere G, Hanff E, Weisman N. Opportunités de développement des biocarburants au Burkina Faso. 2008. p. 134.

[7] Nonyarma E, Laude JP. Policy framework for the development of biofuels in Burkina Faso. Sud Sciences \& Technologies. 2010;19-20.:9.

[8] Yamamoto H, Fujino J, Yamaji K. Evaluation of bioenergy potential with a multi-regional globalland-use-and-energy model. Biomass and Bioenergy. 2001;21:185-203.

[9] Dabat $\mathrm{M}-\mathrm{H}$. Les nouveaux investissements dans les agrocarburants Quels enjeux pour les agricultures africaines ? Afrique contemporaine 2011;237.

[10] Von Maltitz G, Stafford W. Assessing opportunities and constraints for biofuel development in sub-Saharan Africa. Bogor, Indonesia: Center for International Forestry Research (CIFOR); 2011. p. $56 p$.

[11] Azoumah Y, Blin J, Daho T. Exergy efficiency applied for the performance optimization of a direct injection compression ignition (Cl) engine using biofuels. Renewable Energy. 2009;34:1494-500.

[12] Eckart K, Henshaw P. Jatropha curcas L. and multifunctional platforms for the development of rural sub-Saharan Africa. Energy for Sustainable Development. 2012.

[13] Sidibé SS, Blin J, Vaitilingom G, Azoumah Y. Use of crude filtered vegetable oil as a fuel in diesel engines state of the art: Literature review. Renewable and Sustainable Energy Reviews. 2010;14:2748-59.

[14] Blin J, Girard P. Guide technique pour une utilisation énergétique des huiles végétales dans les pays de la CEDEAO. Paris: L'Harmattan; 2011. p. 141 p.

[15] Agarwal D, Agarwal AK. Performance and emissions characteristics of Jatropha oil (preheated and blends) in a direct injection compression ignition engine. Applied Thermal Engineering 2007;27:2314-23.

[16] Hanff E, Dabat MH, Blin J. Are Biofuels an Efficient Technology for Generating Sustainable Development in Oil-Dependent African Nations? A Macroeconomic Assessment of the Opportunities and Impacts in Burkina Faso. Renewable and Sustainable Energy Reviews. 2011;15:2199-209.

[17] Baquero G, Esteban B, Riba J-R, Rius A, Puig R. An evaluation of the life cycle cost of rapeseed oil as a straight vegetable oil fuel to replace petroleum diesel in agriculture. Biomass and Bioenergy. 2011;35:3687-97.

[18] Spinelli D, Jez S, Basosi R. Integrated Environmental Assessment of sunflower oil production. Process Biochemistry. 2012;47:1595-602.

[19] Kojima M, Matthews W, Sexsmith F. Petroleum Markets in Sub-Saharan Africa. World Bank. 2010.

[20] Tatsidjodoung P, Dabat M-H, Blin J. Insights into biofuel development in Burkina Faso: Potential and strategies for sustainable energy policies. Renewable and Sustainable Energy Reviews. 2012;16:5319-30.

[21] Bouffaron P, Castagno F, Herold S. Straight vegetable oil from Jatropha curcas L. for rural electrification in Mali - A techno-economic assessment. Biomass and Bioenergy. 2012;37:298-308.

[22] Mofijur M, Masjuki HH, Kalam MA, Hazrat MA, Liaquat AM, Shahabuddin M, et al. Prospects of biodiesel from Jatropha in Malaysia. Renewable and Sustainable Energy Reviews. 2012;16:5007-20. 
[23] Martin M, Mwakaje AG, Eklund M. Biofuel development initiatives in Tanzania: development activities, scales of production and conditions for implementation and utilization. Journal of Cleaner Production. 2009;17, Supplement 1:S69-S76.

[24] Misra RD, Murthy MS. Jatropha-The future fuel of India. Renewable and Sustainable Energy Reviews. 2011;15:1350-9.

[25] Jain S, Sharma MP. Prospects of biodiesel from Jatropha in India: A review. Renewable and Sustainable Energy Reviews. 2010;14:763-71.

[26] Gmunder SM, Zah R, Bhatacharjee S, Classen M, Mukherjee P, Widmer R. Life cycle assessment of village electrification based on straight jatropha oil in Chhattisgarh, India. Biomass and Bioenergy. 2010;34:347-55.

[27] Blin J, Weisman N, Hanff E, Dabat MH. Vers une stratégie nationale de développement des filières biocarburant : le cas du Burkina Faso. Liaison Énergie-Francophonie. 2011;87 35-45.

[28] Srivastava A, Prasad R. Triglycerides-based diesel fuels. Renewable and Sustainable Energy Reviews. 2000;4:111-33.

[29] Remmele E, Stotz K. Qualitätssicherung bei der dezentralen Pflanzenölerzeugung für den NichtNahrungsbereich Projektphase 1: Erhebung der Ölqualität und Umfrage in der Praxis: Technologieund Förderzentrum; 2003.

[30] Remmele E, Thuneke K, Widmann BA, Wilharm T. Begleitforschung zur Standardisierung von Rapsöl als Kraftstoff für pflanzenöltaugliche Dieselmotoren in Fahrzeugen und BHKW Weihenstephan Quality standard for rapeseed oil. München: Bayersiches Staatsministerium für Ernährung, Landwirtschaft und Forsten 2000. p. 23.

[31] IRAM. Des membres d'Inter-réseaux agissent sur le thème de la valorisation des produits locaux Grain de sel 2012. p. 47.

[32] Remmele E, Thuneke K. Pre-standard DIN V 51605 for rapeseed oil fuel. 15th European Biomass Conference \& Exhibition. Berlin, Germany2007. p. 2612-3.

[33] Codex standard for edible fats and oils not covered by individual standards. Codex alimentarius, International Food Standards. 1999.

[34] Cert A, Moreda W, Perez-Camino MC. Chromatographic analysis of minor constituents in vegetable oils. Journal of Chromatography A. 2000;881:131-48.

[35] Deepak A, Avinash KA. Performance and emissions characteristics of Jatropha oil (preheated and blends) in a direct injection compression ignition engine. Applied Thermal Engineering. 2007;27:1314-2323.

[36] Demirbas A. Biodiesel from vegetable oils via transesterification in supercritical methanol. Energy Conversion and Management. 2002;43:2349-56.

[37] Vaïtilingom G. Huiles végétales - Biocombustible diesel. Influence de la nature des huiles et en particulier de leur composition en acides gras sur la qualité-carburant: Université d'Orleans; 1992.

[38] Amalia Kartika I, Pontalier PY, Rigal L. Extraction of sunflower oil by twin screw extruder: Screw configuration and operating condition effects. Bioresource Technology. 2006;97:2302-10.

[39] Khan LM, Hanna MA. Expression of oil from oilseeds : A review. Journal of Agricultural Engineering Research. 1983;28:495-503.

[40] Willems P, Kuipers NJM, Haan de AB. Hydraulic pressing of oilseeds: Experimental determination and modeling of yield and pressing rates. Journal of Food Engineering. 2008;89:8-16.

[41] Haldar SK, Ghosh BB, Nag A. Studies on the comparison of performance and emission characteristics of a diesel engine using three degummed non-edible vegetable oils. Biomass and Bioenergy. 2009;33:1013-8.

[42] Atabani AE, Silitonga AS, Ong HC, Mahlia TMI, Masjuki HH, Badruddin IA, et al. Non-edible vegetable oils: A critical evaluation of oil extraction, fatty acid compositions, biodiesel production, characteristics, engine performance and emissions production. Renewable and Sustainable Energy Reviews. 2013;18:211-45.

[43] Bredeson D. Mechanical Pressing. Journal of the American Oil Chemists' Society. 1977;54:48990. 
[44] Witzelsperger J, Remmele E. Aftertreatment of Rapeseed Oil Fuel to reduce element contents. 7th European Biomass Conference and Exhibition From Research to Industry and Markets. Hamburg: ETA-Florence Renewable Energies, WIP-Renewable Energies; 2009. p. 1888-93.

[45] Vaitilingom G. Utilisation énergétique de l'huile de coton carburant des moteurs diesels. Cahiers Agricultures vol $15 \mathrm{n}^{\circ} 1.2006$.

[46] Santori G, Di Nicola G, Moglie M, Polonara F. A review analyzing the industrial biodiesel production practice starting from vegetable oil refining. Applied Energy. 2012;92:109-32.

[47] Hafidi A, Pioch D, Ajana H. Membrane-based simultaneous degumming and deacidification of vegetable oils. Innovative Food Science \&amp; Emerging Technologies. 2005;6:203-12.

[48] Toscano G, Riva G, Foppa Pedretti E, Duca D. Vegetable oil and fat viscosity forecast models based on iodine number and saponification number. Biomass and Bioenergy. 2012;46:511-6.

[49] Demirbas A. Fuel properties and calculation of higher heating values of vegetable oils. Fuel. 1998 77:1117-20.

[50] How HG, Teoh YH, Masjuki HH, Kalam MA. Impact of coconut oil blends on particulate-phase PAHs and regulated emissions from a light duty diesel engine. Energy. 2012;48:500-9.

[51] Misra RD, Murthy MS. Straight vegetable oils usage in a compression ignition engine:a review. Renewable and Sustainable Energy Reviews. 2010;14:3005-13.

[52] Hazar $\mathrm{H}$, Aydin $\mathrm{H}$. Performance and emission evaluation of a $\mathrm{Cl}$ engine fueled with preheated raw rapeseed oil (RRO)-diesel blends. Applied Energy. 2010 87:786-90.

[53] Daho T. Contribution à l'étude des conditions optimales de combustion des huiles végétales dans les moteurs Diesel et sur les bruleurs : cas de I'huile de coton [Doctorat unique]: Université de Ouagadougou; 2008.

[54] Ramadhas AS, Jayaraj S, Muraleedharan C. Use of vegetable oils as I.C. engine fuels-A review. Renewable Energy. 2004;29:727-42.

[55] Franco Z, Nguyen QD. Flow properties of vegetable oil-diesel fuel blends. Fuel. 2011;90:838-43.

[56] Russo D, Dassisti M, Lawlor V, Olabi AG. State of the art of biofuels from pure plant oil. Renewable and Sustainable Energy Reviews. 2012;16:4056-70.

[57] Daho T, Vaitilingom G, Sanogo O, Ouiminga SK, Segda BG, Valette J, et al. Study of droplet vaporization of various vegetable oils and blends of domestic fuel oil : cottonseed oil under different ambient temperature conditions. Biomass and Bioenergy. 2012;46:653-63.

[58] Espadafor FJ, García MT, Villanueva JB, Gutiérrez JM. The viability of pure vegetable oil as an alternative fuel for large ships. Transportation Research Part D. 2009.

[59] Esteban B, Riba J-R, Baquero G, Rius A, Puig R. Temperature dependence of density and viscosity of vegetable oils. Biomass and Bioenergy. 2012;42:164-71.

[60] Higelin P. Huiles végétales - Biocombustible diesel. Incidence des aspects thermiques liés au type de moteur sur la combustion. Orléans: Université d'Orléans; 1992.

[61] Rodriguez RP, Sierens R, Verhelst S. Ignition delay in a palm oil and rapeseed oil biodiesel fuelled engine and predictive correlations for the ignition delay period. Fuel. 2011;90:766-72.

[62] Vaïtilingom G. Les huiles végétales biocarburants pour moteurs diesels Montpellier (France): CIRAD UPR 42; 2004.

[63] Haupais A. Combustion dans les moteurs thermiques et environnement. Ed. Techniques Ingénieur; 1992.

[64] Harwood H. Oleochemicals as a fuel: Mechanical and economic feasibility. Journal of the American Oil Chemists' Society. 1984;61:315-24.

[65] Agarwal AK, Rajamanoharan K. Experimental investigations of performance and emissions of Karanja oil and its blends in a single cylinder agricultural. Applied Energy. 2009;86:106-12.

[66] Agarwal AK, Dhar A. Experimental investigations of performance, emission and combustion characteristics of Karanja oil blends fuelled DICl engine. Renewable Energy. 2013;52:283-91.

[67] Agarwal AK, Dhar A. Experimental investigations of preheated jatropha oil fuelled direct injection compression ignition engine - Part 1: Performance, emission, and combustion characteristics. ASTM Special Technical Publication. 2011;1477:337-54.

[68] Knothe G. Historical perspectives on vegetable oil-based diesel fuels. Industrial Olls. 2001;12. 
[69] Bacha J, Freel J, Gibbs A, Gibbs L, Hemighaus G, Hoekman K, et al. Diesel Fuels Technical Review. In: Corporation C, editor.: Chevron Corporation; 2007.

[70] Deustches Institut für Normung e. V. DIN V51605 Kraffstoffe für planzenöltaugliche MotorenRapsölkraftstoff-Anforderungen. Berlin, Beuth-Verlag Gmbh2006.

[71] FAO. Stratégie de gestion des risques de catastrophe en Afrique de l'Ouest et au Sahel (2011 2013). 2011.

[72] Dabat M-H, Fallot A. Conclusions of the international conference on biofuels in Africa :" Biofuels: enhancing development or increasing food insecurity ?" Sud Sciences \& Technologies. 2011;19 \& 20:9-14.

[73] FAO stat. Land use. Statistics Division. 2010.

[74] BEFSCl. Impacts of Bioenergy on Food Security - Guidance for Assessment and Response at National and Project Levels. FAO environment and natural resources management working paper. 2012.

[75] Stan Jones DSJ, Pujad PR. Handbook of Petroleum Processing: Springer; 2006

[76] Speight JG. Handbook of petroleum product analysis. Wiley-Interscience: New York; 2002.

[77] MacKetta JJ. Chemical processing handbook. New York, NY [u.a.]: Dekker; 1993.

[78] Perry RH, Chilton CH, Kirkpatrick SD. Perry's Chemical Engineers' Handbook 4th edition ed1963.

[79] Kopieu G. Mesures Réglementaires Relatives à la Qualité de l'Air, à la Pollution par les Hydrocarbures et à l'Essence sans Plomb :Cas de la Côte d'Ivoire. Elimination du Plomb dans I'Essence en Afrique Sub-Saharienne

Dakar, Sénégal 2002. p. 45.

[80] SONABHY. Société Nationale Burkinabé d'Hydrocarbures, National Fuel Specification 2011.

[81] GTZ. Renewable Energies in West Africa - Regional Report on Potentials and Marktes - 17 Country Analyses. Deutsche Gesellschaft für Technische Zusammenarbeit; 2009.

[82] Graboski MS, McCormick RL. Combustion of fat and vegetable oil derived fuels in diesel engines. Progress in Energy and Combustion Science. 1998;24:125-64.

[83] American Society of Testing Materials Standard D6751-09a Standard Specification for Biodiesel Fuel Blend Stock (B100) for Middle Distillate Fuel, DOI :10.1520/D6751-09. West Conshohocken, PA: ASTM International; 2009.

[84] European Committee for Standardization. EN 14214 Automotive fuels - Fatty acid methyl esters (FAME) for diesel engines - Requirements and test methods. 2010.

[85] Brazilian National Agency of Petroleum Natural Gas and Biofuels. Technical Regulation ANP №7/2008. Diário Oficial da União. 2008; 19.03.2008

[86] Tripartite Task Force: Brazil-European Union \& United States of America. White paper on internationally compatible biofuel standards. 2007.

[87] Monteiro MR, Ambrozin ARP, Lião LM, Ferreira AG. Critical review on analytical methods for biodiesel characterization. Talanta. 2008;77:593-605.

[88] Gaupp K. Pflanzenöle als Dieselkraftstoff. Automobiltechnische Zeitschrift. 1937;8:203-8.

[89] Blauensteiner $\mathrm{H}$. Demonstration of 2 nd generation vegetable oil fuel in advanced engines. Deliverable $\mathrm{N}^{\circ} 3.1$ Survey on oil quality; 2009.

[90] Pryde EH. Vegetable oil fuel standards. Proceedings of the International Conference on Plant and Vegetable Oils as Fuels. St Joseph, Michigan: American Society of Agricultural Engineers (ASAE); 1982. p. 101-5.

[91] Remmele E, Stotz K, Witzelsperger J, Gassner T. Qualitätssicherung bei der dezentralen Pflanzenölerzeugung für den Nicht-Nahrungsbereich Technologische Untersuchunger und Erarbeitung von Qualitätssicherungmassnahmen: Technologie-und Förderzentrum; 2007.

[92] Möller F. Energy forum. Alternative motor fuels. Vegetable oil as diesel replacement. Energie Forum Alternative kraftstoffe Pflanzenöl als dieselersatz. 2006;58:33.

[93] De Almeida SCA, Belchior CR, Nascimento MVG, Vieira LdSR, Fleury G. Performance of a diesel generator fuelled with palm oil. Fuel. 2002;81:2097-102.

[94] Sapuan SM, Masjuki HH, Azlan A. The Use of Palm Oil as Diesel Fuel Substitute Proceedings of the Institution of Mechanical Engineers, Part A: Journal of Power and Energy

1996;210:47-53. 
[95] Bari S, Lim TH, Yu CW. Effects of preheating of crude palm oil (CPO) on injection system, performance and emission of a diesel engine. Renewable Energy. 2002;27:339-51.

[96] Gumpon P, Teerawat A. Palm Oil as a Fuel for Agricultural Diesel Engines: Comparative Testing against Diesel Oil. Songklanakarin Journal of Science and Technology. 2003;25.

[97] Pandey RK, Rehman A, Sarviya RM. Impact of alternative fuel properties on fuel spray behavior and atomization. Renewable and Sustainable Energy Reviews. 2013;16:1762-78.

[98] Liu K-T, Gao S, Chung T-W, Huang C-m, Lin Y-S. Effect of process conditions on the removal of phospholipids from Jatropha curcas oil during the degumming process. Chemical Engineering Research and Design. 2012;90:1381-6.

[99] Singh SP, Singh D. Biodiesel production through the use of different sources and characterization of oils and their esters as the substitute of diesel: a review. Renewable and Sustainable Energy Reviews. 2010;14:200-16.

[100] Giannelos PN, Zannikos F, Stournas S, Lois E, Anastopoulos G. Tobacco seed oil as an alternative diesel fuel: physical and chemical properties. Industrial Crops and Products. 2002;16:1-9.

[101] Moser BR, Vaughn SF. Evaluation of alkyl esters from Camelina sativa oil as biodiesel and as blend components in ultra low-sulfur diesel fuel. Bioresource Technology. 2011;101:646-53.

[102] Knothe G. Analyzing biodiesel: standards and other methods. Journal of the American Oil Chemists' Society. 2006;83:823-33.

[103] Wärtsilä. Fuel-flexibility, liquid-fuels. In: http://www.wartsila.com/en/powerplants/technology/fuel-flexibility/liquid-fuels, editor.2012

[104] Hoekman SK, Broch A, Robbins C, Ceniceros E, Natarajan M. Review of biodiesel composition, properties, and specifications. Renewable and Sustainable Energy Reviews. 2012;16:143-69.

[105] Lapuerta Mn, RodrÃ-guez-FernÃindez J, de Mora EF. Correlation for the estimation of the cetane number of biodiesel fuels and implications on the iodine number. Energy Policy. 2009;37:4337-44.

[106] Ryan T, Dodge L, Callahan T. The effects of vegetable oil properties on injection and combustion in two different diesel engines. Journal of the American Oil Chemists' Society. 1984;61:1610-9.

[107] Mondal P, Basu M, Balasubramanian N. Direct use of vegetable oil and animal fat as alternative fuel in internal combustion engine. Biofuels, Bioproducts and Biorefining. 2008;2:155-74.

[108] 14112 E. Fat and oil derivatives - Fatty Acid Methyl Esters (FAME) - Determination of oxidation stability (accelerated oxidation test). 2003.

[109] D2274 A. Standard test method for oxidation stability of distillate fuel oïl (accelerated method). 2010.

[110] Direction de l'Energie du Senegal, Direction l'Environnement et des Etablissements Classés du Senegal, Direction des Transports Terrestres du Senegal. Communication du Senegal sur les mesures relevant des ministeres de l'energie, de l'environnement et du transport. iniative sur la qualite de l'air dans les villes d'afrique sub-saharienne. Dakar.2002.

[111] Diaouré O. Pollution atmosphérique :aspects législatifs et réglementaires. UNEP: aspects législatifs et réglementaires aspects législatifs et réglementaires aspects législatifs et réglementaires2009.

[112] Liennard A, Pioch D, Chirat N, Lozano P, Vaitilingom G. Energy generation from "neat" vegetable oils. In: SCIELO, editor. In Procedings of the 4th Encontro de Energia no Meio Rural,. Campinas 2002.

[113] Chaves ES, dos Santos EJ, Araujo RGO, Oliveira J, Frescura VLA, Curtius AJ. Metals and phosphorus determination in vegetable seeds used in the production of biodiesel by ICP OES and ICPMS. Microchemical Journal. 2010;96:71-6.

[114] De Jongh J, Adriaans A, Adriaans T. Jatropha oil quality related to use in diesel engines and refining methods: technical note-FACT report. 2007.

[115] Pryor JN, Bogdanor JM, Welsh WA. Process for the removal of chlorophyll, color bodies and phospholipids from glyceride oils using acid-treated silica adsorbents. EU1994.

[116] Zschau W. Die Bleichung von Speisefetten und Ölen VII. Verwendung gebrauchter Bleicherde. Aus dem Arbeitskreis "Technologien der industriellen Gewinnung und Verarbeitung von Speisefetten". Lipid / Fett. 1999;101:347-50. 
[117] Remmele E, Widmann BA, Wachs B. Umweltverträglichkeit von Hydraulikölen auf Rapsölbasis beim Einsatz in mobilen Aggregaten sowie Möglichkeiten der Wiederverwendung, Verwertung und Entsorgung. Abschlußbericht der Bayer Landesanstalt für Landtechnik, Freising-Weihenstephan und des Bayerische Landesamtes für Wasserwirtschaft München 1997. p. 154.

[118] International Standard Organisation. ISO 10540-1:2003 Animal and vegetable fats and oils Determination of phosphorus content - Part 1: Colorimetric method. 2003.

[119] Silveira ELC, de Caland LB, Tubino M. Molecular absorption spectrophotometric method for the determination of phosphorus in biodiesel. Fuel. 2011;90:3485-8.

[120] Szydlowska-Czerniak A, Szlyk E. Spectrophotometric determination of total phosphorus in rape seeds and oils at various stages of technological process: calculation of phospholipids and nonhydratable phospholipids contents in rapeseed oil. Food Chemistry. 2003;81:613-9.

[121] ISO 663:2007. Animal and vegetable fats and oils. Determination of insoluble impurities content. 2007.

[122] Hodac I, McCurdy D, Mandel JR, Nao Y. Biodiesel guidelines. In: Committee WFC, editor.2009. p. 24.

[123] Elsbett. Vegetable Oil Standard; http://www.elsbett.com/gb/vegetable-oil/vegetable-oilstandard.html. 2012.

[124] FAO. Graines oléagineuses, huiles et farines d'oléagineux. Perspectives de l'alimentation, SMIAR. 2011;novembre 2011:47-131.

[125] Karmakar A, Karmakar S, Mukherjee S. Properties of various plants and animals feedstocks for biodiesel production. Bioresource Technology. 2010;101:7201-10.

[126] ISO 660:2009. Animal and vegetable fats and oils. Determination of acid value and acidity. 2009.

[127] ISO 3961:2009. Animal and vegetable fats and oils. Determination of iodine value. 2009.

[128] ISO 8534:2008. Animal and vegetable fats and oils. Determination of water content -- Karl Fischer method (pyridine free). 2008.

[129] ISO 10540-1:2003. Animal and vegetable fats and oils. Determination of phosphorus content. Part 1: Colorimetric method. 2003. 